Article

\title{
Investigation of Copper Recovery from a New Copper Ore Deposit (Nussir) in Northern Norway: Dithiophosphates and Xanthate-Dithiophosphate Blend as Collectors
}

\author{
Priyanka Dhar*, Maria Thornhill and Hanumantha Rao Kota \\ Department of Geoscience and Petroleum, Norwegian Institute of Science and Technology, 7032 Trondheim, \\ Norway; maria.thornhill@ntnu.no (M.T.); hanumantha.rao.kota@ntnu.no (H.R.K.) \\ * Correspondence: priyanka.dhar@ntnu.no
}

Received: 12 January 2019; Accepted: 21 February 2019; Published: 28 February 2019

\begin{abstract}
The Norwegian mining industry is currently showing increasing interest in the production of metals. Recent research has demonstrated promising results identifying the high potential of the Nussir deposit for the production of copper and other valuable minerals. Mineralogical characterization for Nussir ore samples and their flotation concentrates was performed with optical microscopy and Zeiss automated mineralogy (Mineralogic) where the fine copper sulphide middlings were not completely recovered with a traditional sodium isobutyl xanthate (SIBX) collector. In the current study, dithiophosphate and a mixture of xanthate and dithiophosphate collectors' interaction on copper and other gangue mineral components of the ore sample were investigated with zeta potential, quantitative adsorption, FTIR studies and Hallimond tube flotation. All the results for single mineral experiments confirmed the feasibility of selective copper sulphide flotation by disecondary butyl dithiophosphate (DBD) as collector. The blend of xanthate and dithiophosphate was chemically adsorbed as individual entities on the surface of the copper minerals via competitive adsorption. A systematic study with DBD and a mixed collector (SIBX and DBD) system was conducted on the coarse grind $(-105 \mu \mathrm{m})$ of the Nussir ore sample, and the results showed a synergistic interaction between the two reagents. The beneficiated copper concentrate using this mixture of collectors is indeed of improved copper grade and recovery. The highest copper recovery in bench scale flotation was $95.3 \%$ with a concentrate grade of $19.4 \% \mathrm{Cu}$ for DBD collector, whereas mixtures of dithiophosphate and xanthate collectors in the ratio of $3: 1$ resulted in the highest copper grade $(24.7 \%)$ and recovery $(96.3 \%)$.
\end{abstract}

Keywords: Nussir ore; chalcopyrite; chalcocite; bornite; calcite; quartz; zeta potential; hallimond flotation; bench scale flotation

\section{Introduction}

Nussir ASA, located in the Kvalsund area of Finnmark, is exploring the Nussir and Ulveryggen deposits, and production is anticipated to begin in the near future. With a metal endowment totalling ca. $6 \%$ copper, Nussir is one of the largest deposits in Norway. Nussir copper ore is comprised within a relatively simple deposit with very high-grade copper minerals, and the presence of other iron sulphide impurities are negligible in the ore. The latest mineral resource estimation is from July 2014, which states that Nussir consists of 5.8 million tonnes of indicated resources and 60.2 million tonnes of inferred resources, giving 66 million tonnes of copper ore. This ore contains approximately from $0.5 \%$ to $6 \%$ copper, which varies significantly based on geographical location. The copper mineralogy mainly consists of chalcopyrite, chalcocite and bornite [1], and the ore has very little inclusion of iron 
sulphides. The deposit also contains some traces of economically interesting elements such as silver, gold and platinum group elements (PGE). The traditional method for processing copper sulphide ores is by flotation, which is both economical and suitable as per the environmental standards. The most important factor in flotation of sulphides is the choice of reagents for optimum flotation. A priori, the advanced mineralogy and surface properties of these minerals in this ore deposit are necessary for a judicious choice of the collector for flotation to recover valuable minerals.

Automated mineralogical characterization using energy-dispersive scanning electron microscopy (SEM-EDS) is gaining significance in mineral processing operations because of its ability to collect statistically valid quantitative data on mineral distributions, liberation and associations. This data adds precise information on particulates that have traditionally been characterized by bulk mineralogical and chemical methods and optical microscopy. Dhar et al. [2] found that the percentage of liberation of $\mathrm{Cu}$ sulphides is approximately $80 \%$ for the Nussir ore sample at $-105 \mu \mathrm{m}$. This study shows that a major part of the copper is present in middlings, which were difficult to recover using the traditional xanthate collector.

Earlier, in the development of ore processing flotation, xanthates were almost always employed as collectors for flotation performed on metal sulphides. Due to the high selectivity of dithiophosphates, these collectors were also employed for selective copper sulphide flotation, and a few studies explained the interaction of dithiophosphates with pure copper minerals [3-7]. The mechanism of copper mineral flotation with dithiophosphates is believed to be the chemical adsorption of the dithiophosphate collector by the formation of cuprous dithiophosphate in neutral and slightly alkaline conditions. Recently, Zhong et al. [8] indicated that the recovery of pure chalcopyrite was high in the presence of dithiophosphinate even at natural $\mathrm{pH} 8$ (of the ore) and further showed optimum flotation results of bench scale flotation of a copper ore at the same $\mathrm{pH}$. In the current study, the adsorption and interaction mechanism of disecondary butyl dithiophosphate (DBD) was investigated using pure minerals and bench scale flotation tests which were performed on Nussir ore samples as a function of $\mathrm{pH}$ and collector concentration. Additionally, the response of the DBD collector towards chalcopyrite, chalcocite and bornite has been presented and compared with xanthate as a collector.

In the past, Glembotskii [9] demonstrated that when a weaker collector is added to a stronger collector, the mixture results in an increase in recovery as compared to the individual strong collector system. Later, Bradshaw et al. [10,11] and Lotter and Bradshaw [12] reviewed the use of various mixtures of collectors in sulphide flotation where the selectivity and, thereby, the recovery and grade increase depending on the proportions of constituents of the collector blend. Additionally, the same authors indicated that the recoveries of middlings could be increased with the usage of mixtures of collectors in optimum ratios. A synergistic interaction of the collectors results in a greater adsorption, which increases the hydrophobicity of the desired mineral.

The synergism of the collectors in blends is generally explained with bench scale flotation or microflotation studies; only a few studies were performed on the basis of adsorption results. In 1980, Wakamatsu et al. [13] reported the co-adsorption of collectors at low concentrations and the competitive adsorption at high concentrations of ethyl xanthates (EX) and dibutyl dithiophosphate (DBDTP) collectors in the region of $\mathrm{pH}$ 6-7 for galena. Adsorption studies were performed with the solution depletion/abstraction method, and they stated that the adsorption of xanthates increased and DBDTP decreased for the equimolar mixtures of both the collectors at higher collector concentrations. Alternatively, Corin et al. [14] found no evidence of a synergistic effect between diethyl dithiophosphate (DEDTP) and isobutyl xanthate (IBX) for a platinum group ore. The authors reported that the dithiophosphate led to the stabilization of the froth phase and did not contribute to enhancing the hydrophobicity of the mineral surface. However, McFadzean et al. $[15,16]$ showed that a significant increase in pure mineral flotation was observed in the presence of DEDTP and IBX collector mixtures for galena. They clarified that the improvement in the flotation performance relies on the sequence of collector addition. Additionally, the same authors, in 2013, observed synergism in the batch flotation of pyrite with a mixture of IBX and DEDTP. 
Woods [7] studied xanthates and dithiocarbamate mixtures and explained that the chemisorbed collector species were more evenly distributed on the mineral surface than physisorbed species. A mixture may result in a balance of better distributed, more strongly held chemisorbed species and more hydrophobic neutral physisorbed dithiolates, and this could result in the formation of a multilayer surface product that is more strongly attached to the mineral surface. Bagci et al. [17] and Critchley and Riaz [18] proposed that the adsorption is improved by the addition of a weaker but more selective collector (dithiophosphate) before the less selective collector (SIBX).

This paper represents the first study on processing characteristics of the Nussir ore to date. In the process of developing a flowsheet for Cu-recovery, dithiophosphate and its blend with xanthate are examined as candidates for the flotation collector to beneficiate the ore. Since the Nussir ore is free from iron impurities, a successful collector selection would be of benefit to future copper deposits of similar mineral constitution. Based on the literature, the mixture of xanthate and dithiophosphate collectors in different proportions is studied in this paper to find the best reagent scheme for Nussir ore flotation. This collector blend is capable of reducing production costs and potentially providing an increase in efficiency in terms of copper recovery and grade. The information from this study will then contribute and assist the detailed flowsheet development being performed in parallel in collaboration with SGS mining and Woodgrove, Canada. Prior to this, the adsorption of both the individual collectors in the collector mixture (SIBX-DBD) on copper sulphide minerals were evaluated using adsorption studies. To our knowledge, no studies have been reported explaining the nature and quantity of adsorption of dithiophosphates and xanthates on copper sulphides. An attempt has been made to demonstrate the mixed dithiophosphate and xanthate adsorption on the copper minerals with quantitative and qualitative adsorption studies together with zeta potential, pure mineral and bench scale flotation studies.

\section{Materials and Methods}

Pure mineral rock specimens of chalcopyrite ( $>92 \%$ grade), chalcocite ( $>93 \%$ grade) and bornite ( $>91 \%$ grade) were purchased commercially. The samples were obtained from Sweden, England and Austria respectively. Pure crystalline calcite and quartz samples used in these experiments were obtained from Norway. The sample preparation procedure for zeta potential measurements, FTIR studies, adsorption studies and Hallimond flotation tests was a three-fold process: (i) crushing using a jaw crusher with $3 \mathrm{~mm}$ discharge-opening, (ii) milling using a ball mill followed by sieving to collect the size range from -150 to $+45 \mu \mathrm{m}$ to be used in the Hallimond flotation (iii) for the zeta potential, adsorption studies and FTIR experiments. A portion of the $-45 \mu \mathrm{m}$ sample was further milled in a Fritsch Pulverisette 6 (Idar-Oberstein, Germany) planetary mono mill and wet screened to $-10 \mu \mathrm{m}$. Precautions were taken during the whole milling and sieving process until the initial conditioning phase for the Hallimond flotation or zeta potential experiments to ensure that surface oxidation did not affect the results.

The Nussir ore (Figure 1) material was collected from two different parts (panels) of the mine, Nussir North East (N-NE) and Nussir Old West (N-OW). For bench scale flotation tests, the samples were thoroughly mixed, crushed and milled to $-105 \mu \mathrm{m}$ (coarse grind).

Cytec Solvay group supplied the reagents used in these experiments. The molecular weight of DBD used in the preparation of collector solutions was $264 \mathrm{~g} \cdot \mathrm{mol}^{-1}$, (as specified by the manufacturer). Methyl isobutyl carbinol (MIBC) was employed as the frother. The $\mathrm{pH}$ was adjusted with dilute solutions of reagent-grade milli $\mathrm{Q}$ water of $\mathrm{HCl}$ and $\mathrm{NaOH}$. Deionized water was used in all the studies with a pure mineral system, whereas tap water was used for the bench scale flotation tests. Additionally, a standard quartz suspension was used for calibrating the zeta potential instrument. Copper nitrate was employed to prepare the Cu-precipitates with a DBD collector for FTIR analysis. The Brunauer-Emmett-Teller (BET) surface areas for the $-10 \mu \mathrm{m}$ size fraction of chalcopyrite, chalcocite and bornite were $0.98,1.31$ and $1.01 \mathrm{~m}^{2} \cdot \mathrm{g}^{-1}$ respectively. 


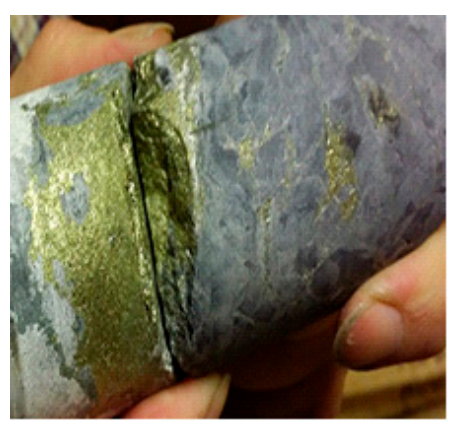

(a)

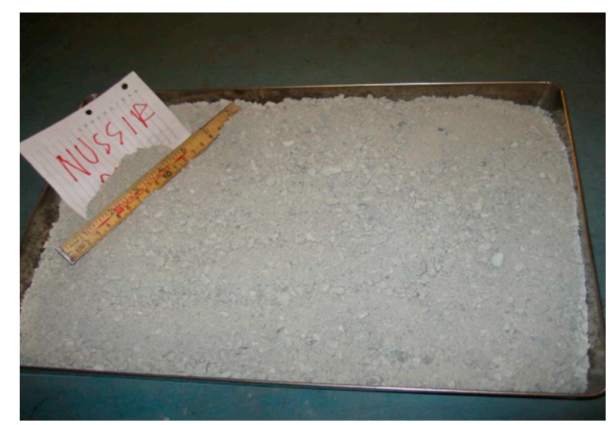

(b)

Figure 1. (a) The Nussir drill hole specimen: Veinlets of chalcocite and bornite on a carbonate structure; (b) the crushed ore sample received from Nussir ASA.

\subsection{Zeiss Mineralogical Mining Method}

All samples were initially examined by optical microscopy. Subsequent automated mineralogy analyses were performed with the Zeiss Mineralogic Mining System at the Department of Materiaux et Environnement, Université de Liège, Belgium.

The Zeiss Mineralogic Mining System is a new generation of Automated Mineralogy systems designed to provide information on the modal mineralogy (by area $\%$ and wt $\%$ ), morphology of analysed grains/particles, mineral liberation, locking characteristics, mineral association, chemical assay and element deportment. Data acquisition by the Mineralogic was performed using a Zeiss Sigma 300 field emission gun equipped with two Bruker EDX detectors (XFlash ${ }^{\circledR} 630$ SDD energy dispersive spectrometer). The operating conditions used for the data acquisition were a $20 \mathrm{kV}$ acceleration voltage, a current of $20 \mathrm{nA}$, a $8.5 \mathrm{~mm}$ working distance and a "full mapping" analytical mode. Analyses were conducted on selected representative areas of the whole specimen with a mapping step size of $3 \mu \mathrm{m}$ and from 0.025 to 0.03 seconds of dwelling time.

For the microscopic observations, approximately $1 \mathrm{~g}$ of representative sample was embedded in a mixture made with $0.4 \mathrm{~g}$ of PRINTEX®carbon black powder, $15 \mathrm{~mL}$ of epoxy resin and $2 \mathrm{~mL}$ of hardener to obtain blocks of $3 \mathrm{~cm}$ diameter. The addition of carbon black avoids the grain settlement by density into resin and allows a good spatial dispersion of particles [19].

\subsection{Zeta Potential Measurements}

The zeta potential measurements were performed using a DT-300 system instrument from Quantachrome/Dispersion Technologies, which works on the electroacoustic techniques principle. The chalcopyrite, chalcocite, bornite, quartz and calcite samples were first analysed in the particle size analyser to obtain the mean particle diameter. A $2 \mathrm{~g}$ sample of pure mineral was transferred into a $100 \mathrm{~mL}$ beaker containing $50 \mathrm{~mL}$ solution of a desired $\mathrm{pH}$ and concentration of DBD. Conditioning was performed in the following order before recording the titration experiments in the $\mathrm{pH}$ range from 2 to 12: (i) a pH adjustment for $5 \mathrm{~min}$ and (ii) collector addition for $5 \mathrm{~min}$. During titration, the $\mathrm{pH}$ was adjusted using $1 \mathrm{M} \mathrm{HCl}$ and $1 \mathrm{M} \mathrm{NaOH}$. The conductivity and $\mathrm{pH}$ of the suspension were monitored continuously during the measurement, and the ambient temperature was maintained at $22 \pm 0.5^{\circ} \mathrm{C}$. All experiments were performed in triplicate, and an average result was reported.

\subsection{Adsorption Measurements}

Adsorption experiments of DBD and mixed DBD-SIBX collectors on copper sulphide surfaces were performed with a UV-2401PC (Shimadzu, Kyoto, Japan) spectrometer. A calibration curve was established using the UV-spectra taken for $50 \mathrm{~mL}$ of different aqueous DBD solutions (from $1 \times 10^{-7}$ to $2 \times 10^{-3} \mathrm{M}$ ). The $\mathrm{pH}$ of the solution was adjusted to approximately 8.2 with $1 \mathrm{M} \mathrm{HCl}$ and $1 \mathrm{M} \mathrm{NaOH}$. To these collector solutions, $2 \mathrm{~g}$ of $-10 \mu \mathrm{m}$ each of chalcopyrite, chalcocite and bornite was added and stirred for $30 \mathrm{~min}$. The suspensions were further filtered, and the supernatant solutions were 
characterised in a UV-Visible spectrometer (with required dilution). The amount of dithiophosphate adsorbed was calculated from the difference between initial and residual concentration of the solutions.

Another set of experiments were performed using mixtures of dithiophosphate and xanthate collectors in 1:1 ratio under similar conditions. The characteristic peaks of SIBX and DBD were used for the estimation of the amount of dithiophosphate and xanthate adsorbed.

\subsection{FTIR Measurements}

Mineral samples conditioned with the desired collector(s) concentration and specified $\mathrm{pH}$ from the quantitative adsorption studies were dried and analysed with a Bruker Vertex 80v Infrared spectrometer. A typical FTIR spectrum was an average of 200 scans measured at a $4 \mathrm{~cm}^{-1}$ resolution with a narrow band liquid nitrogen cooled MCT detector. The pure mineral powder was used as a reference while recording the spectra of the reagent-treated mineral samples. The spectra of copper sulphides conditioned with 1:1 xanthate and dithiophosphate were also analysed by an infrared spectrometer. Additionally, the spectra of the minerals, reagent and $\mathrm{Cu}$-dithiophosphate precipitates were noted for reference. The atmospheric water was always subtracted from the sample spectrum. The area under the alkyl chain bands and the intensities of functional group bands were measured with the facility available within spectral manipulation.

\subsection{Hallimond Tube Flotation Experiments}

The Hallimond flotation tests were conducted with $2 \mathrm{~g}$ from -150 to $+50 \mu \mathrm{m}$ size chalcopyrite, chalcocite, bornite, calcite and quartz samples in a $100 \mathrm{~mL}$ Hallimond tube flotation cell. The first step was to adjust the desired $\mathrm{pH}$ level using $\mathrm{HCl}$ and $\mathrm{NaOH}$. Afterwards, the collector and frother were added and conditioning was performed for 5 and $2 \mathrm{~min}$ respectively in a $100 \mathrm{~mL}$ standard volumetric flask. The sample was conditioned with a magnetic stirrer for the respective time and subsequently transferred to the Hallimond flotation cell. Air was supplied at the rate of $8 \mathrm{ml} \cdot \mathrm{min}^{-1}$, and flotation time was $1 \mathrm{~min}$. The floated and tailing fractions were collected separately, dried and weighed. The flotation cell was thoroughly washed using ethanol and subsequently rinsed with deionized water after each experiment. All experiments were performed in triplicate, and an average result was reported.

\subsection{Bench Scale Flotation Tests}

The bench scale flotation experiments were performed with $200 \mathrm{~g}$ (-105 $\mu \mathrm{m}$ size fraction) of ore, wet ground with tap water in a steel mill with a $1 \mathrm{~kg}$ grinding medium followed by flotation in a Maelgwyn bench scale flotation cell of $1 \mathrm{~L}$ capacity. The following reagents were added in sequence: a $\mathrm{pH}$ regulator, collectors and a frother, the dosages of which varied from one experiment to another. The impeller speed and airflow rate were fixed at $1200 \mathrm{rpm}$ and $3 \mathrm{~L} \cdot \mathrm{min}^{-1}$, respectively. The flotation was performed in two stages, where the total flotation time was $4 \mathrm{~min}$. The resulting purified copper sulphide concentrates were filtered, dried and chemically analysed with a Bruker AXS S8 Tiger Wavelength Dispersive XRF.

\section{Results}

\subsection{Mineralogy}

The ore consists primarily of chalcopyrite, chalcocite and bornite with a minimal amount of covellite. A SEM image is presented in Figure 2, which represents all the copper sulphides in the ore. The presence of economically valuable precious metal minerals in low quantities was also noted. Mineralogical characterisation revealed that the copper minerals from the panel N-NE are dominated by bornite and chalcocite with a small amount of chalcopyrite, while the N-OW composite is rich in bornite and chalcopyrite with small amounts of chalcocite. In our previous investigations, the flotation experiments performed with xanthate as a collector showed that the maximum grade and recovery were $14 \%$ and $91 \% \mathrm{Cu}$, respectively [20]. 
Before and after the bench scale flotation of the ore with xanthate, the feed and float materials analyzed with Mineralogic revealed that a significant quantity of copper sulphides in the feed material are associated with other copper sulphides, silicate and carbonate minerals. The middlings percentage in both the samples for the $-105 \mu \mathrm{m}$ range is approximately $10 \%-17 \%$. Although the ore is relatively simple, with little or no intrusion of iron sulphides, the silicate and carbonate gangue minerals are finely disseminated within the matrix of ore samples. The overall distribution of the various associations of copper sulphides before and after flotation with xanthate and dithiophosphate and these two collectors in the blend (1:1) is presented in Figure 3.

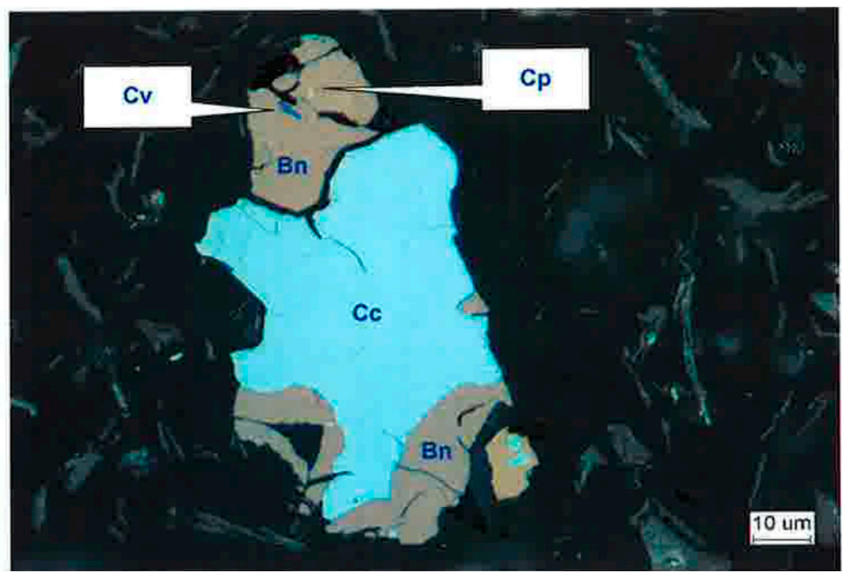

Figure 2. A photomicrograph of the copper sulphides present in the ore. Cc-chalcocite; Bn—bornite; $\mathrm{Cp}$-chalcopyrite; $\mathrm{Cv}$ - covellite.

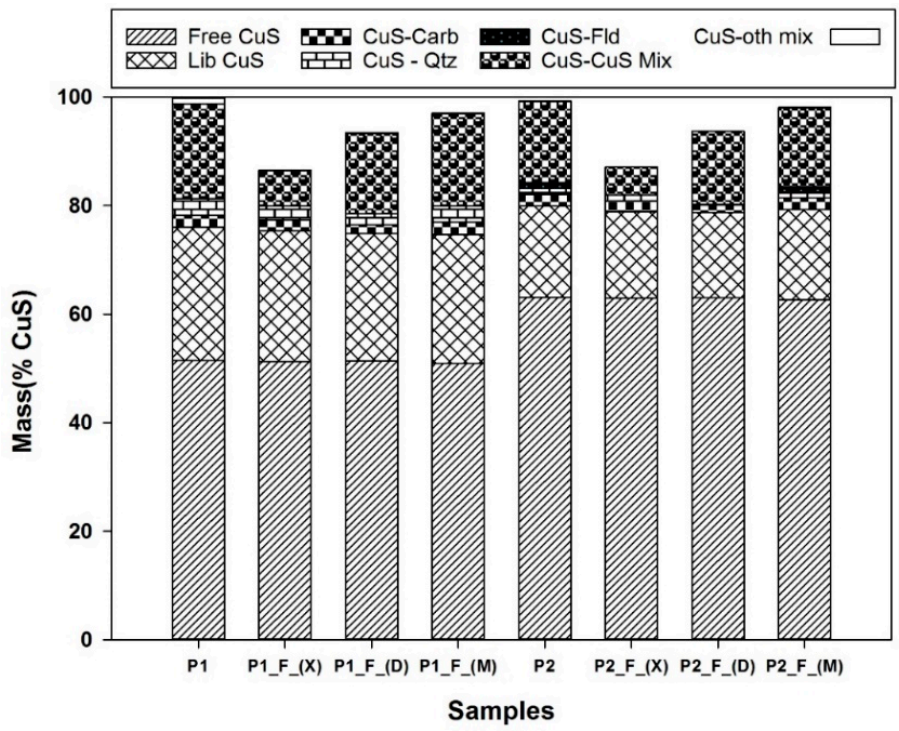

Figure 3. The distribution of various associations of copper sulphides in the Old West (N-OW; P1) and Nussir North East (N-NE; P2) samples at collector concentration $3 \times 10^{-5} \mathrm{M}$ and $\mathrm{pH}$ 8.2. P1 and P2-Feed; F-Flotation product; $\mathrm{X}$-sodium isobutyl xanthate (SIBX); D—disecondary butyl dithiophosphate (DBD); $\mathrm{M}-\mathrm{SIBX}: \mathrm{DBD}=1: 1$ ratio (Liberated: $>80 \%$ liberation; Free: Fully liberated; and Middling: $<80 \%$ liberation).

The liberated copper sulphides were clearly floated when using SIBX as a collector, while a significant amount of middlings did not float with xanthate at collector concentration $3 \times 10^{-5} \mathrm{M}$. It is noticeable that the flotation of copper sulphide-carbonate/silicate blends (CuS-carb/CuS-Qtz) is equally efficient as the copper sulphide-copper sulphide (CuS-CuS) blends in the presence of xanthate collectors. Apparently, at the same collector dosage, a considerable amount (ca. $8 \%-10 \%)$ of 
copper sulphide middlings (specifically CuS-CuS blends) were able to float with a DBD collector; less flotation of CuS-carb/CuS-Qtz is observed. Moreover, a substantial amount of associated mixed copper sulphide particles were floated, together with CuS-carb/CuS-Qtz blend minerals in the presence of the mixture of SIBX and DBD collector. The results are in agreement with the previous findings that SIBX is a stronger (more reactive) collector and that DBD is more selective towards copper sulphides [10]. Earlier, a few researchers [11] also observed improvement in coarse particle recovery and middlings recovery with collector mixtures on $\mathrm{Cu} / \mathrm{Pt}$ ores. Therefore, dithiophosphate and dithiophosphate-xanthate blends were studied as collectors, and an extensive investigation has been made to assess the interaction of these collectors with the pure copper sulphide minerals. Detailed bench scale flotation results as a function of $\mathrm{pH}$ and collector concentration are presented later in the flotation section.

\subsection{Zeta Potential Studies}

The zeta potential values of chalcopyrite, chalcocite, bornite, calcite and quartz were measured as a function of $\mathrm{pH}$ in aqueous solution, and the results are presented in Figure 4. The isoelectric points (IEPs) of chalcopyrite and chalcocite are located at $\mathrm{pH} 4$ and 4.3 respectively. The IEPs of bornite are at two $\mathrm{pH}$ values, 2.8 and 6. Zhao et al. [21], Kelebek and Smith [22], and Fullston et al. [23] reported similar results. The IEP of gangue minerals, calcite and quartz, are at $\mathrm{pH} 8.2$ and 2.1. These values are in agreement with previously reported results by Somasundaran [24]. In Figures 4 and 5, the zeta potential values decrease with increasing $\mathrm{pH}$ values in the presence and absence of the collector. There is a shift towards negative zeta potential values after the addition of the anionic DBD collector, which signifies the adsorption of the reagent on the copper sulphide surface and the mode of adsorption is chemisorption on $\mathrm{Cu}$-sites, which is later shown by the FTIR studies. It is evident that the zeta potential values of copper sulphides also decreased with the subsequent addition of SIBX [2]. However, the copper sulphides conditioned with DBD show more negative potentials (in the $\mathrm{pH}$ range 4-9) as compared to those conditioned with SIBX. Overall, it is observed that the zeta potential values of copper sulphides decrease significantly in the acidic and neutral $\mathrm{pH}$ region, whereas in alkaline $\mathrm{pH}$, there is a minimal decrease in zeta potential values.

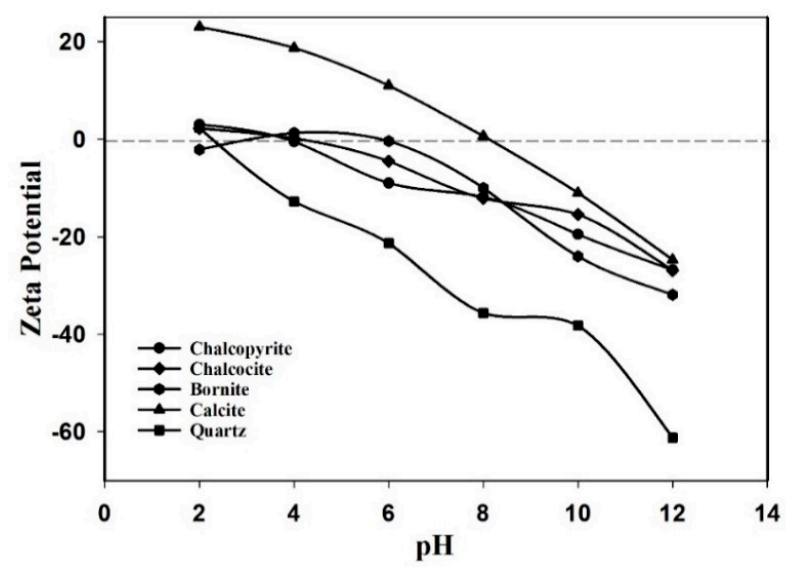

Figure 4. The zeta potential of copper minerals and gangue minerals in aqueous solution.

The zeta potential values of copper sulphides conditioned with mixtures of the collector (total collector concentration: $3 \times 10^{-5} \mathrm{M}$ ) are shown in Figure 6. A major shift towards negative values in the zeta potentials of copper sulphides is observed in the $\mathrm{pH}$ range 6-10. It is noted that when the fraction of $\mathrm{DBD}$ is greater in the reagent mixture, the values of zeta potential are more negative. This is consistent with the single collector systems, where values of zeta potential were more negative for copper sulphides conditioned with DBD as compared to SIBX [2]. In addition, the negative potentials of copper sulphides are higher in the mixed reagent system compared to a single reagent system, 
indicating an adsorption of both the collectors on the surface of the copper minerals. It is also noted that the behaviour of different copper sulphides is largely dependent on the composition of the reagents employed in the experiments. Less variation in zeta potential values in the presence of different compositions of DBD-SIBX mixtures is observed as compared to bornite and chalcopyrite ( $\mathrm{Cu}-\mathrm{Fe}$ sulphides). The presence of different active sites of $\mathrm{Cu}$ and Fe would be achieved due to the different degrees of their oxidation sites. The flotation behaviour of these copper sulphide minerals in the presence of DBD and collector blends is further examined with Hallimond tube flotation experiments.

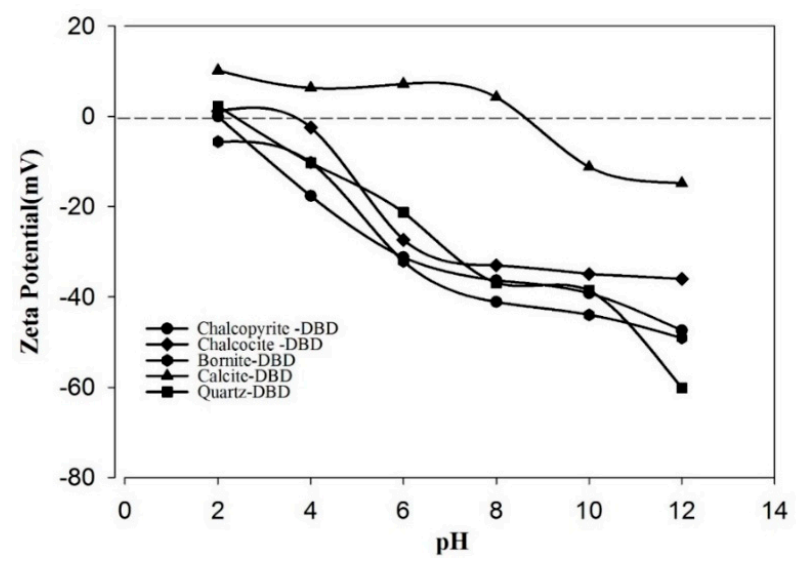

Figure 5. The zeta potentials of minerals as a function of $\mathrm{pH}$ at DBD concentration $5 \times 10^{-5} \mathrm{M}$.

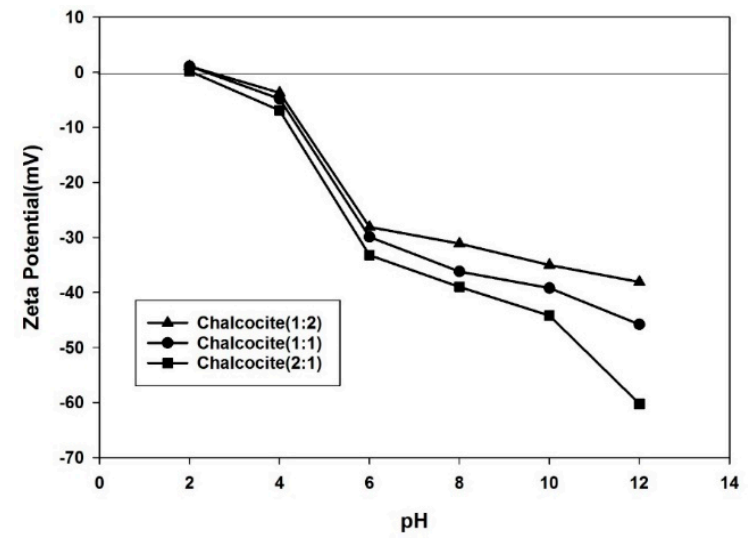

(a)

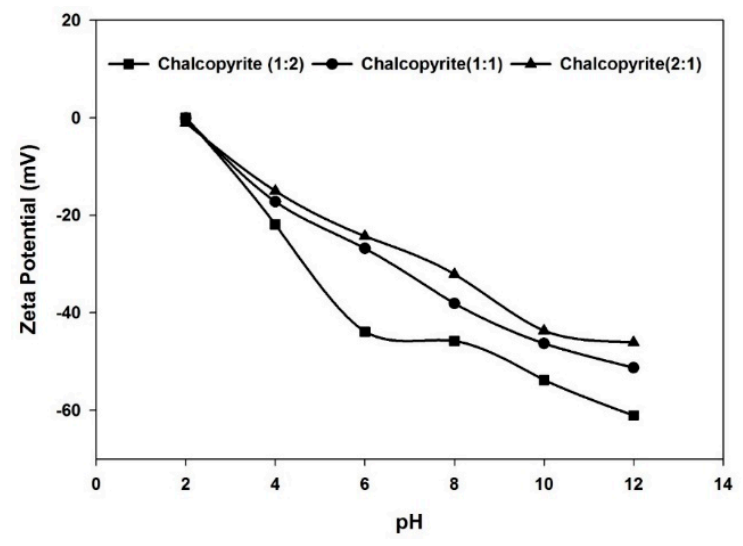

(b)

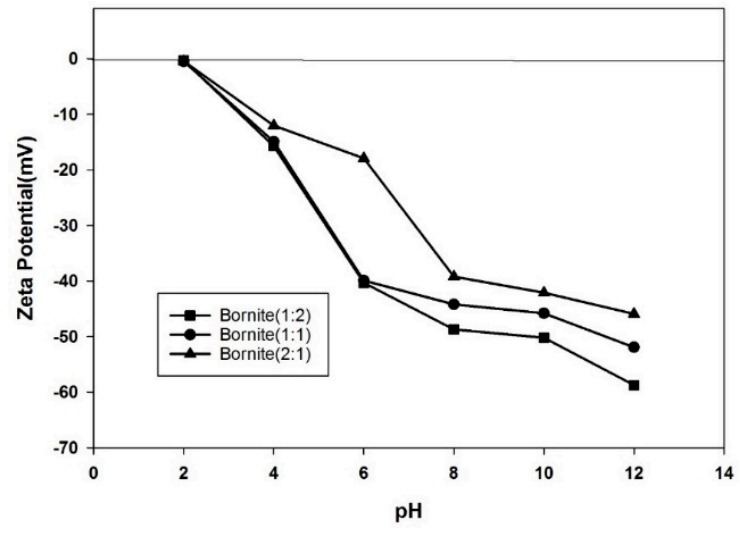

(c)

Figure 6. The zeta potentials of (a) chalcopyrite, (b) chalcocite, and (c) bornite as a function of $\mathrm{pH}$ in presence of collector mixture (SIBX:DBD). 


\subsection{Hallimond Flotation Studies}

The floatability of chalcopyrite, chalcocite, bornite, calcite and quartz in the presence of DBD is investigated as a function of $\mathrm{pH}$ (Figure 7). In this figure, the highest recoveries for all the three sulphides were observed for $\mathrm{pH} \approx 6$, while the recoveries are also considerably high at $\mathrm{pH} 8-9$. At acidic $\mathrm{pH}$ values, the recoveries of chalcocite, chalcopyrite and bornite are low, while the recoveries are consistently more than $70 \%$ above $\mathrm{pH}$ 5. However, the recovery of copper sulphides, specifically chalcopyrite, is relatively less at $\mathrm{pH}$ 12. It is known that the copper-iron sulphides are oxidised more in alkaline solutions as compared to acidic or neutral solutions. In fact, the precipitation of metal species as hydroxides is predominantly prevalent in alkaline $\mathrm{pH}$ values. Therefore, recovery decreased in alkaline $\mathrm{pH}$ solutions and is due to the heavy surface coating hydrophilic metal hydroxides [5,25]. The high recovery of copper sulphides signifies a high selectivity of DBD in a wide $\mathrm{pH}$ range (pH 4-11).

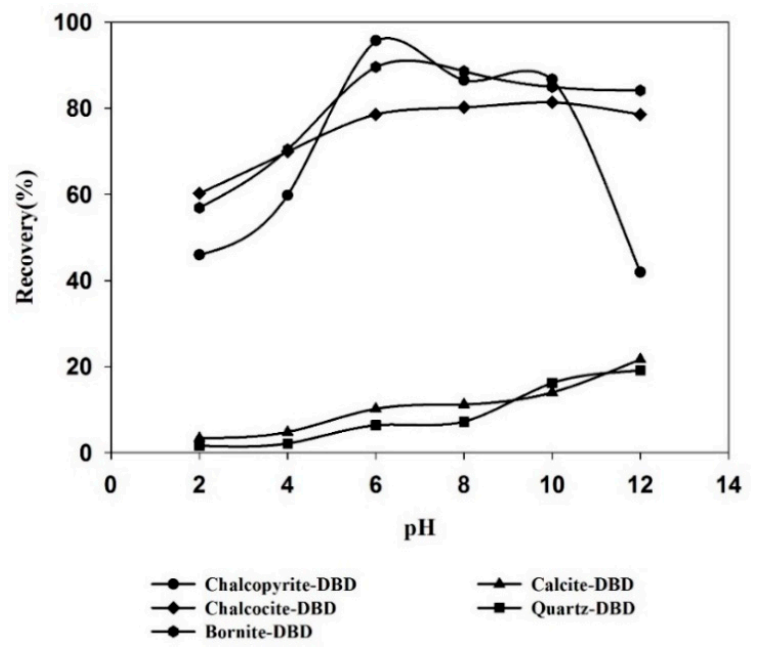

Figure 7. The Hallimond flotation recovery as a function of $\mathrm{pH}$ at collector concentration $5 \times 10^{-5} \mathrm{M}$.

Figure 8 depicts the recovery of pure mineral flotation as a function of collector concentration at a natural $\mathrm{pH}$. The results are very similar to our earlier findings on flotation of copper sulphides with SIBX as the collector. However, it is noticeable that a lesser amount of DBD is required as compared to SIBX for a higher flotation of copper sulphides. Chalcopyrite and bornite show a sudden rise in recovery at collector concentration $1 \times 10^{-5} \mathrm{M}$, whereas chalcocite shows a steady increase in recovery. In general, the flotation response of chalcopyrite and bornite is slightly higher than chalcocite. These results are consistent with the zeta potential results. The recovery of calcite and quartz also increases to $20 \%-30 \%$ at a high collector concentration: ca. $1 \times 10^{-4} \mathrm{M}$. All the comparisons with xanthate are performed based on our earlier investigation [20].

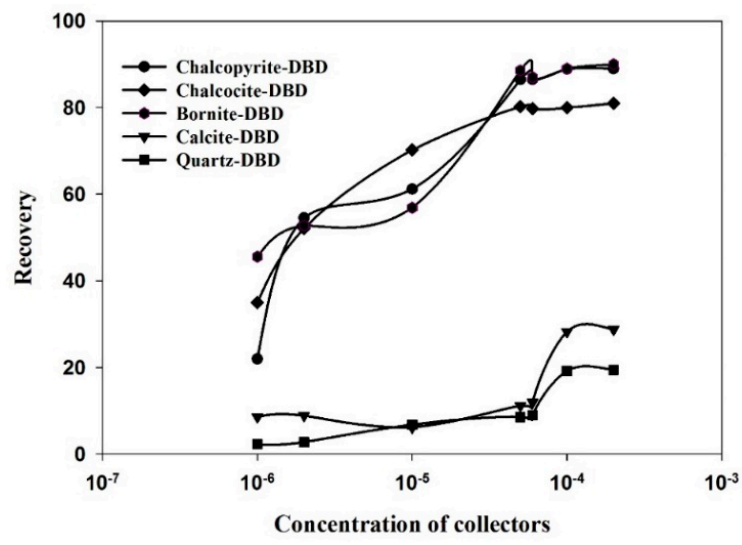

Figure 8. Hallimond flotation recovery as a function of collector concentration at a natural $\mathrm{pH}$. 
The floatability studies of pure minerals with collector mixtures at a natural $\mathrm{pH}$ and total collector concentration $3 \times 10^{-5} \mathrm{M}$ is shown in Figure 9. The recoveries of pure chalcopyrite and bornite minerals have two maxima, at $\mathrm{pH} 6$ and 9, when SIBX:DBD is 1:2. However, when SIBX:DBD = 1:2, the recovery of chalcocite showed a maximum recovery at $\mathrm{pH} 8 / 9$. These results are in agreement with the outcomes of individual reagent systems, where chalcocite indicated higher recoveries at $\mathrm{pH} 8$, whereas chalcopyrite and bornite indicated a maximum recovery at $\mathrm{pH} 6$. The recoveries of calcite and quartz are significantly lower for all the three different ratios. In general, it is observed that the synergistic action of both the reagents results in better recoveries than an individual collector scheme for all the single pure minerals. The major advantage of using collector mixtures is the total concentration of collectors required for flotation of copper sulphides is relatively lower than the single collector system. The improvements in the SIBX:DBD mixture are understandably due to a simple case of competitive adsorption (explained later in Section 3.4 adsorption studies) where DBD adsorbs on the higher active sites followed by the adsorption of the more reactive xanthate collectors on the remaining low activity sites.

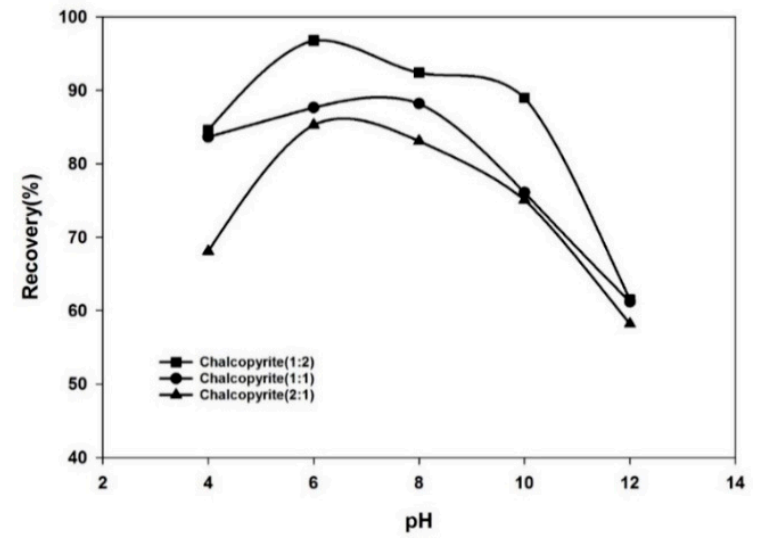

(a)

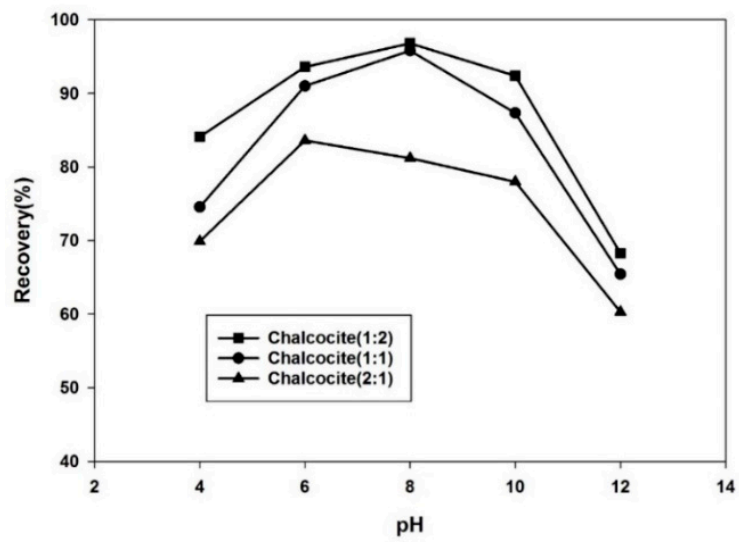

(b)

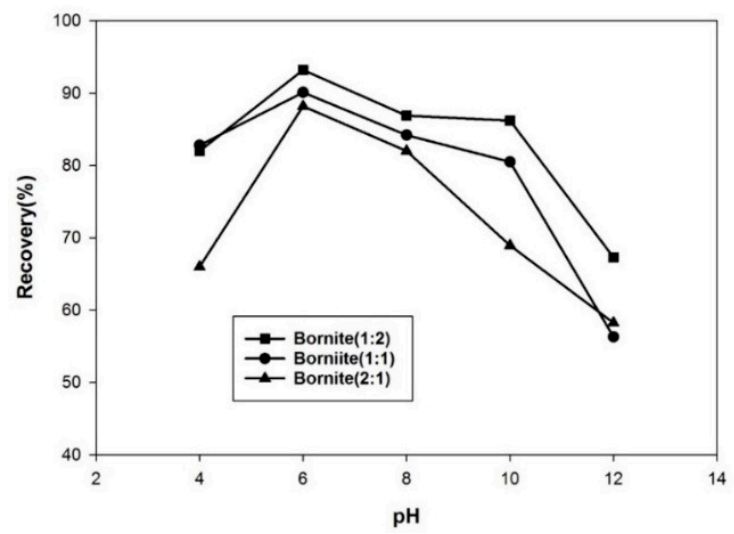

(c)

Figure 9. The Hallimond flotation recovery of (a) chalcopyrite, (b) chalcocite, and (c) bornite in the presence of a collector blend as a function of $\mathrm{pH}$ at collector concentration $3 \times 10^{-5} \mathrm{M}$.

\subsection{Adsorption Studies}

The adsorption of DBD from aqueous solution onto copper minerals has been studied by the solution depletion method using a UV-Visible spectrometer. The high intensity characteristic peak of DBD was observed at $226 \mathrm{~nm}$ [25]. The adsorption mechanism of a mixture of the collectors was also investigated at a 1:1 ratio of SIBX and DBD by using the same spectroscopy method at $\mathrm{pH} 8$. The characteristic peaks at $301 \mathrm{~nm}$ and $226 \mathrm{~nm}$ of SIBX and DBD respectively were present in the spectra, allowing the adsorption of individual collectors from the mixture. A feeble dixanthogen peak was 
observed in the spectra (only at high concentrations), but the dimer of dithiophosphates was not present in the UV spectra because this dithiophosphate dimer has far lower solubility, $5 \times 10^{-7} \mathrm{~mol} \cdot \mathrm{dm}^{-3}$, as compared to dixanthogen $\left(1.25 \times 10^{-5} \mathrm{~mol} \cdot \mathrm{dm}^{-3}[6]\right)$.

The adsorption isotherms of DBD on chalcopyrite, chalcocite and bornite at $\mathrm{pH} 8$ are shown in Figure 10. This figure shows that the adsorption of DBD on chalcopyrite and bornite begins at a lower equilibrium concentration while the onset of adsorption for chalcocite is found to be $9.2 \times 10^{-6} \mathrm{M}$. Initially, when a copper sulphide is introduced to the reagent solution, the mineral surface is hydrated due to the faster diffusion of water molecules compared to bulk ligand molecules (Raju and Forsling [26]). Further, the chemical adsorption of DBD on the $\mathrm{Cu}^{2+}$ sites of copper minerals occurs which is also observed from the FTIR spectra, resulting in a hydrophobic surface. Considering the cross-sectional area of a DBD molecule as $35.4 \AA^{2}$ (as calculated by Matsuoka and Ichikoku [27]), a monolayer is anticipated to form at an adsorption density of $4.6 \mu \mathrm{mol} \cdot \mathrm{m}^{-2}$. In Figure 11, the isotherm of chalcopyrite attains the plateau value at $3.6 \mu \mathrm{mol} \cdot \mathrm{m}^{-2}$, thus indicating a $0.8 \mathrm{monolayer}$. Previously, Petrus et al. [28] observed less than a monolayer coverage of dithiophosphate on chalcopyrite at an equilibrium concentration $1.54 \times 10^{-5} \mathrm{M}$. Our findings are in accordance with these studies, indicating less than a monolayer adsorption on the chalcopyrite surface followed by a sudden increase in adsorption density above concentration $1.87 \times 10^{-4} \mathrm{M}$. The increase after a plateau region can be attributed to precipitate formation in the bulk of solution, or another assertion can be multilayers of surface product are adsorbed on the chemisorbed monolayer $[7,17,25]$. The chalcocite-xanthate adsorption isotherm indicates a marginal increase in adsorption density, followed by a steep rise in the slope which corresponds to the onset of adsorption due to the accumulation of the collector at equilibrium concentration $9.2 \times 10^{-6} \mathrm{M}$. These results show a less than monolayer coverage of DBD on bornite where the adsorption density is merely $3.2 \mu \mathrm{mol} \cdot \mathrm{m}^{-2}$. The bornite isotherm also depicts less than monolayer coverage, and the isotherm levels off at $2.8 \mu \mathrm{mol} \cdot \mathrm{m}^{-2}$. In addition, the chalcocite and bornite isotherms also indicate an increasing adsorption density at a high concentration of DBD $\left(\approx 1 \times 10^{-3} \mathrm{M}\right)$ corresponding to an increase in adsorption in the form of $\mathrm{Cu}(\mathrm{DBD})+(\mathrm{DBD})_{2}$ species of collector on the chemisorbed layer $[4,10]$.

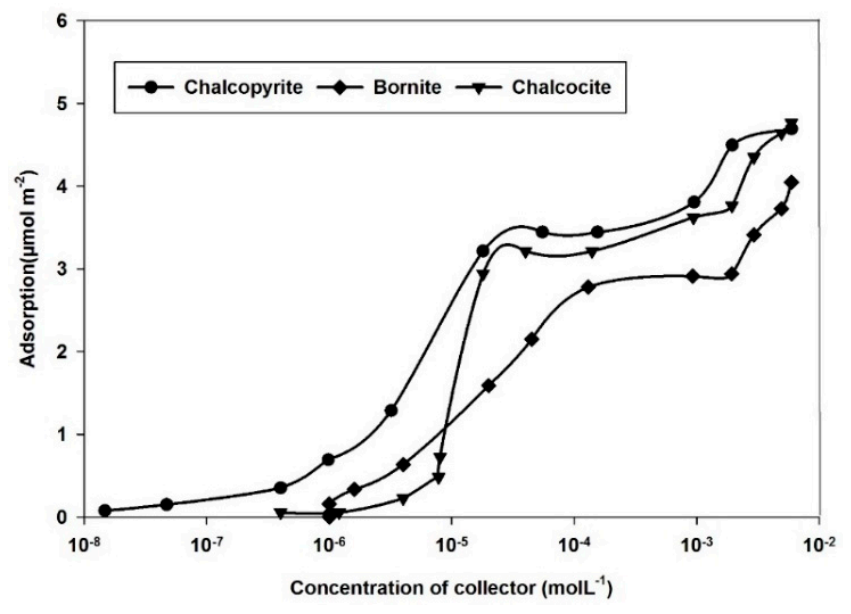

Figure 10. The adsorption of dithiophosphate on the copper sulphide surface at $\mathrm{pH} 8$.

Figure 11 shows the area under the alkyl chain region between $2600-2900 \mathrm{~cm}^{-1}$ (the spectra are presented later in Section 3.5 FTIR) for all the three copper minerals with respect to DBD concentration. The area under the alkyl chain bands was measured with the facility available within the spectral manipulation feature. Adsorption begins at low concentration of collector for chalcopyrite and bornite, while the onset of adsorption for chalcocite was observed at $1 \times 10^{-5} \mathrm{M}$. These results are in agreement with the quantitative adsorption results. The area under the alkyl chain values for chalcopyrite, bornite and chalcocite is approximately constant above collector concentration of $2 \times 10^{-5} \mathrm{M}, 8 \times 10^{-5} \mathrm{M}$ and $2 \times 10^{-5} \mathrm{M}$ respectively. The same figure also depicts the intensities of the characteristic functional 
group band of DBD as a function of collector concentration. The intensities of DBD absorbance bands at 964 and $953 \mathrm{~cm}^{-1}$ for chalcopyrite and chalcocite respectively are nearly constant above $2 \times 10^{-5} \mathrm{M}$. The intensity of the characteristic DBD band for bornite at $949 \mathrm{~cm}^{-1}$ is approximately constant above $1 \times 10^{-4} \mathrm{M}$ in accordance with the quantitative adsorption results. Although not shown in this communication, the FTIR spectra recorded at higher concentrations clearly showed the presence of randomly oriented collector species on the top of chemisorbed layers.

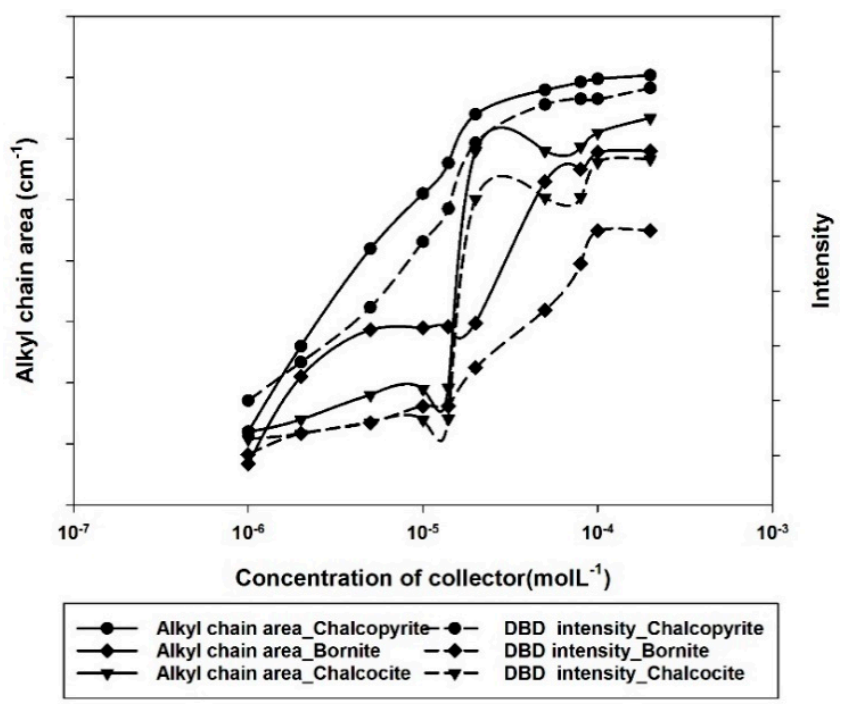

Figure 11. The intensities of the characteristic DBD band and the area under the alkyl chain bands for chalcopyrite, chalcocite and bornite.

Figures 12 and 13 shows the adsorption isotherms of SIBX and DBD on copper minerals in the presence of both these collectors' mixture (1:1) at $\mathrm{pH}$ 8. In general, both the collectors in the mixture are adsorbed on all the three copper minerals. However, the differences in the functional groups of SIBX and DBD influence the chemical reactions between the collector and mineral surface. The independent isotherms of SIBX and DBD depicts less than a monolayer coverage $(\theta)$ of the individual reagent on chalcopyrite. The adsorption corresponds precisely to $0.24 \theta$ of SIBX and $0.6 \theta$ of DBD on chalcopyrite. Similarly, based on the two plots, the proportion of DBD adsorbed on chalcocite is more than SIBX, and both reagents show less than a monolayer coverage. In the case of both chalcopyrite and chalcocite, the onset of adsorption for DBD is at a relatively lower concentration than SIBX, indicating competitive adsorption of the collectors. Alternatively, for bornite, the commencement of adsorption of SIBX is at a comparatively lower concentration than DBD. However, the quantity of adsorption of both the collectors is comparable above the equivalent concentration $5.2 \times 10^{-5} \mathrm{M}$. The stability of the resulting species at the surface is also dependent on the differences in the proportions of reagents in the collector blend, which is not covered in this study. Bagci et al. [17] indicated that dithiophosphinates are more selective to copper sulphides as compared to xanthates, based on the electronegativities of the functional groups. In this study, DBD preferentially adsorbs on chalcopyrite and chalcocite in accordance with Bagci et al. [17]. However, the preferential adsorption of SIBX on bornite is probably due to the presence of Fe in the lattice, which could be a result of different oxidation sites. Previously, Ackerman et al. [29] also reported a decrease in the floatability of bornite in the alkaline pH region, whereas the flotation response of chalcopyrite and chalcocite was high. Therefore, the decrease in adsorption density may lead to a decrease in floatability; similarly, in our pure mineral flotation results, a small decrease in flotation response of bornite is observed. Unlike Wakamatsu et al. [13], our study shows the co-adsorption of collectors at high concentrations; xanthates being more reactive shows a greater adsorption than DBD. 


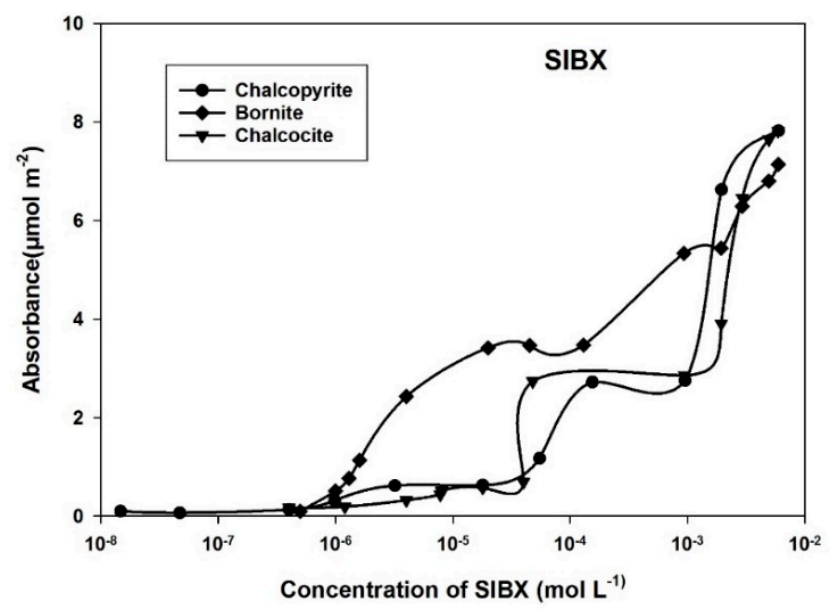

Figure 12. The adsorption of xanthate from a mixture of xanthate and dithiophosphate on the copper sulphide surface at $\mathrm{pH} 8$.

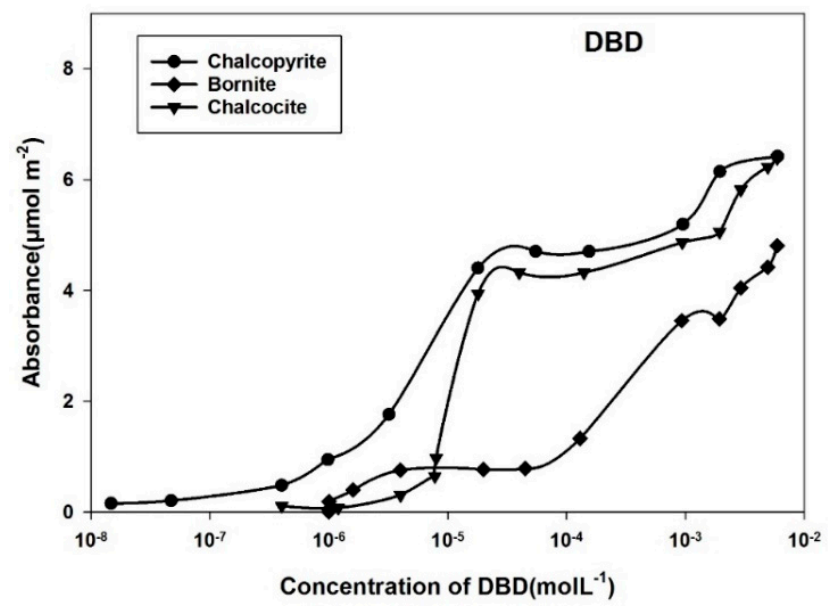

Figure 13. The adsorption of dithiophosphate from a mixture of xanthate and dithiophosphate on the copper sulphide surface at $\mathrm{pH} 8$.

Figure 14 shows the intensities of characteristic SIBX and DBD bands for all the three copper minerals in the presence of mixtures of both the collectors. The intensities of the distinctive DBD peak at $985 \mathrm{~cm}^{-1}$ are more than the SIBX peak at $1065 \mathrm{~cm}^{-1}$ for chalcopyrite. In the case of chalcocite, the intensities of the characteristic DBD peak at $895 \mathrm{~cm}^{-1}$ are greater than the SIBX peak at $1192 \mathrm{~cm}^{-1}$. For bornite, the SIBX peak at $1206 \mathrm{~cm}^{-1}$ is of a higher intensity than that of the DBD peak at $745 \mathrm{~cm}^{-1}$. These results corroborate the quantitative adsorption studies shown in Figures 11 and 12. SIBX preferentially adsorbed on bornite and the quantity of adsorption are comparable to DBD. The area under the alkyl chain for both the collectors is represented in Figure 15, and the results show that the areas under the alkyl chain for all the three copper minerals are approximately constant above cumulative concentration $1 \times 10^{-5} \mathrm{M}$. Future works within this study will investigate the various proportions of collectors in the blend.

In general, the surfaces of the copper sulphides comprise various degrees of surface-active sites. It is understood that when the collector mixture is introduced in the mineral solution, the selective collector first adsorbs on the strong active sites [7]. The less selective collector there will adsorb on the residual weak sites. The different molecular structures of the functional groups of xanthates and dithiophosphates influences the reactions between the collector and mineral surface and, thus, the stability of the species at the surface. Donor atoms are crucial in the interaction between collectors and the mineral surface. Collectors having highly electronegative donor atoms possess a higher affinity for adsorption and are considered as less selective collectors. Thus, the selectivity of the collectors can be 
explained with their respective electro negativities. Nagraj [30] stated that the electronegativities (EN) of $\mathrm{O}$ and $\mathrm{C}$ atom in xanthate molecules are higher than the $\mathrm{P}$ atoms in the structure of dithiophosphates; thus, the selectivity of DBD is higher than SIBX.

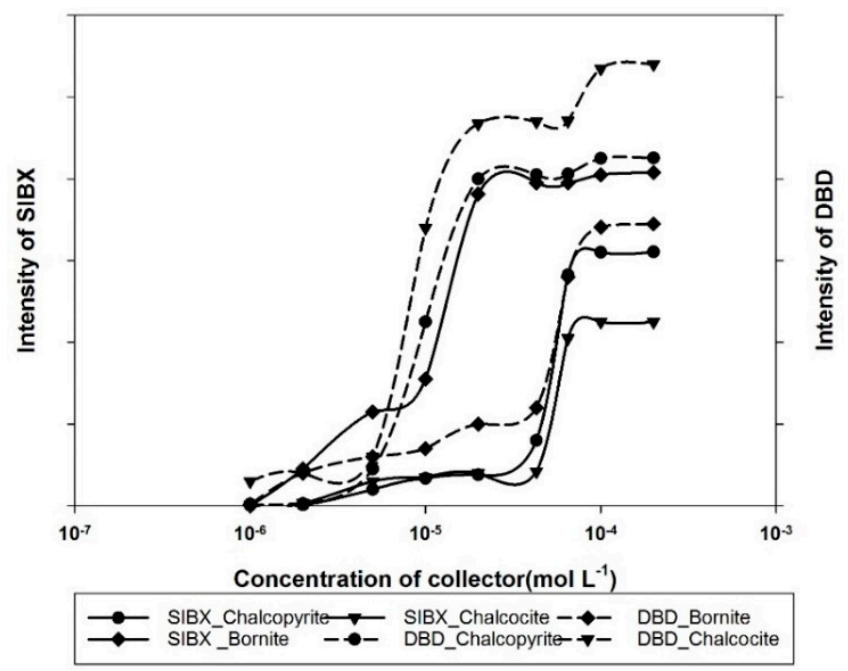

Figure 14. The intensities of characteristic SIBX and DBD bands for chalcopyrite, chalcocite and bornite.

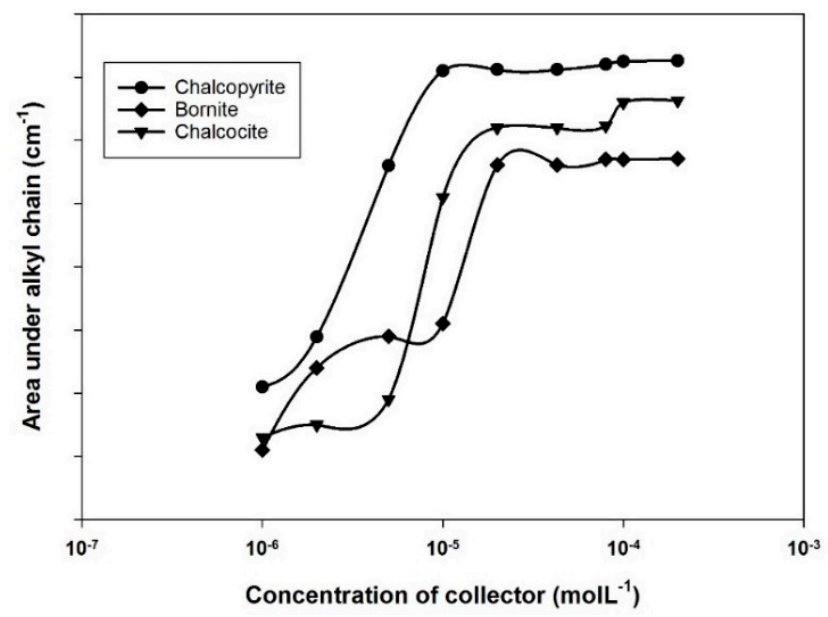

Figure 15. The area under the alkyl chain bands for chalcopyrite, chalcocite and bornite in the presence of SIBX and DBD blend (1:1).

Our adsorption study demonstrates that DBD is adsorbed first on the chalcopyrite and chalcocite surfaces followed by SIBX on the weak sites. A similar competitive adsorption is observed for bornite, where SIBX adsorbs first and, subsequently, DBD adsorbs, which is due to the different degrees of oxidation.

\subsection{FTIR Studies}

The DRIFT spectra of pure copper sulphide minerals, SIBX, DBD and the Cu-precipitate $\left(\mathrm{CuDBD}+\mathrm{Cu}(\mathrm{DBD})_{2}\right)$ as reference spectra are shown in Figure 16. The dithiophosphate and copper-dithiophosphate precipitate spectra indicated a band structure especially below $980 \mathrm{~cm}^{-1}$ (in the region $500-970 \mathrm{~cm}^{-1}$ ). The vibrational bands between $510-575 \mathrm{~cm}^{-1}$ represent $\mathrm{P}-\mathrm{S}$ stretching bands and between $630-830 \mathrm{~cm}^{-1}$ correspond to $\mathrm{P}-\mathrm{O}-\mathrm{C}$ symmetric stretching vibrations [31-33]. The bands between 900 and $1100 \mathrm{~cm}^{-1}$ are attributed to $\mathrm{P}-\mathrm{O}-\mathrm{C}$ asymmetric stretching vibration [32,33]. In the collector spectrum, the bands at $735,787,828$ and $860 \mathrm{~cm}^{-1}$ represent $\mathrm{P}-\mathrm{O}-\mathrm{C}$ symmetric stretching. The bands at 531 and $614 \mathrm{~cm}^{-1}$ indicate $\mathrm{P}-\mathrm{S}$ stretching and $\mathrm{P}=\mathrm{S}$ stretching modes respectively; 
these peaks are attributed to the $\mathrm{PS}_{2}$ group of DBD. The broad peak at $984 \mathrm{~cm}^{-1}$ signifies $\mathrm{P}-\mathrm{O}-\mathrm{C}$ asymmetric stretching vibration. The copper precipitate spectrum indicates characteristic peaks at $523 \mathrm{~cm}^{-1}$ and $642 \mathrm{~cm}^{-1}$ which correspond to $\mathrm{P}-\mathrm{S}$ stretching and $\mathrm{P}=\mathrm{S}$ stretching modes respectively. Additionally, this spectrum shows a peculiar sharp peak at $970 \mathrm{~cm}^{-1}$ which refers to $\mathrm{P}-\mathrm{O}-\mathrm{C}$ asymmetric stretching vibration.

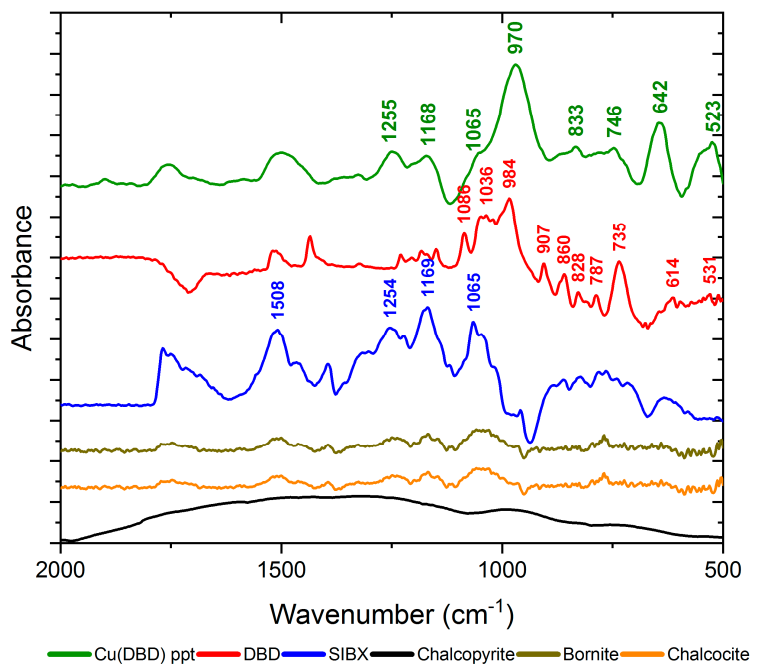

Figure 16. The DRIFT spectra of xanthate, dithiophosphate and copper dithiophosphate precipitates.

Figures 17-19 represent the FTIR spectra of chalcopyrite, bornite and chalcocite conditioned with various concentrations of DBD. After the interaction with DBD, the characteristic peaks for pure chalcopyrite become weak and the characteristic peak $\left(984 \mathrm{~cm}^{-1}\right)$ of DBD becomes evident. The spectra of chalcopyrite in Figure 17 reveals the presence of a peak at $964 \mathrm{~cm}^{-1}$ at and above a $1 \times 10^{-5} \mathrm{M}$ concentration, which corresponds to the asymmetric $\mathrm{P}-\mathrm{O}-\mathrm{C}$ stretching of DBD. The bands at $777 \mathrm{~cm}^{-1}$ and $531 \mathrm{~cm}^{-1}$ refer to $\mathrm{P}-\mathrm{O}-\mathrm{C}$ symmetric stretching and $\mathrm{P}-\mathrm{S}$ stretching vibrations. The shift in $\mathrm{P}-\mathrm{O}-\mathrm{C}$ and $\mathrm{P}-\mathrm{S}$ vibrations indicate the chemical adsorption of the collector on $\mathrm{Cu}$-sites of chalcopyrite.

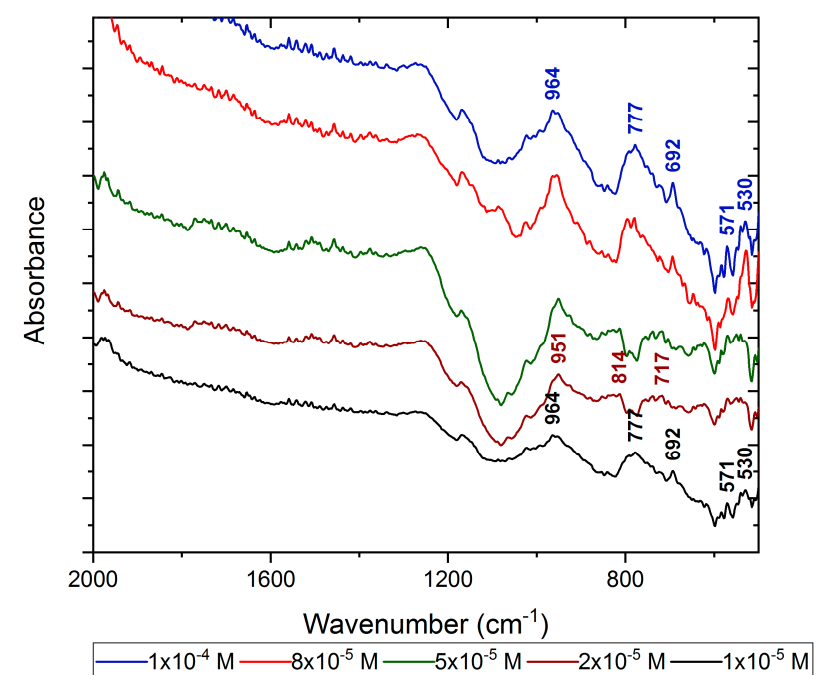

Figure 17. The DRIFT spectra of dithiophosphate adsorption on chalcopyrite with increasing collector concentration.

Similarly, the spectra of bornite and chalcocite conditioned with various concentrations of DBD are shown in Figures 18 and 19. For bornite, a shift is observed in the P-O-C symmetric and asymmetric stretching vibrations of DBD to 814 and $949 \mathrm{~cm}^{-1}$ respectively. The peak at $623 \mathrm{~cm}^{-1}$ which is related 
to $\mathrm{P}=\mathrm{S}$ stretching vibrations is observed at and above a $8 \times 10^{-5} \mathrm{M}$ concentration of the collector, indicating the chemisorption of the collector on $\mathrm{Cu}$ sites. In the case of chalcocite, 953 and $685 \mathrm{~cm}^{-1}$ peaks can be noted, which correspond to $\mathrm{P}-\mathrm{O}-\mathrm{C}$ stretching, and the band below $600 \mathrm{~cm}^{-1}$ refers to $\mathrm{P}=\mathrm{S}$ stretching vibration (dithiolate formation). The shift in $\mathrm{P}-\mathrm{O}-\mathrm{C}$ stretching and $\mathrm{P}=\mathrm{S}$ stretching vibration is related to the chemisorption of DBD on the chalcocite surface. All the changes suggested that the $S$ and $\mathrm{O}$ atoms in the functional group of DBD might have taken part in the reaction with these ions.

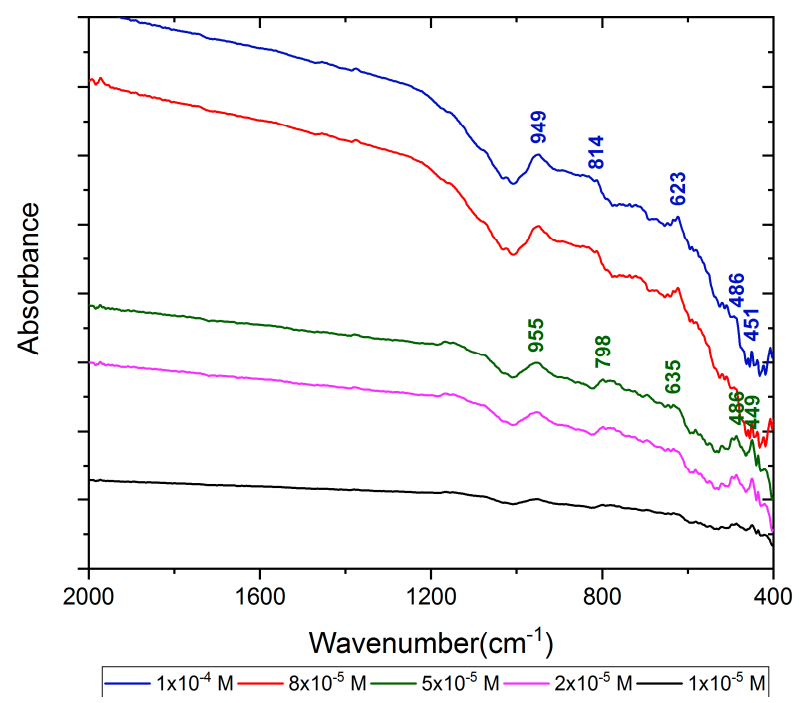

Figure 18. The DRIFT spectra of dithiophosphate adsorption on bornite with increasing collector concentration.

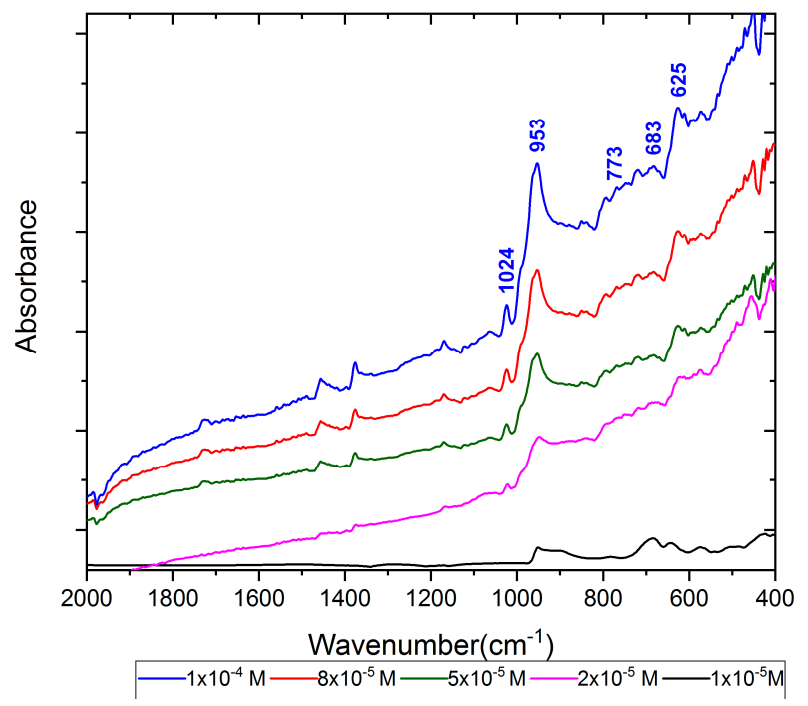

Figure 19. The DRIFT spectra of dithiophosphate adsorption on chalcocite with increasing collector concentration.

Figure 20 depicts the spectra of adsorption of a mixed xanthate and dithiophosphate collector (1:1) at $\mathrm{pH} 8$ on the three copper minerals. The characteristic xanthate bands are between 900 and $1300 \mathrm{~cm}^{-1}$, and the dithiophosphate bands are between 600 and $1000 \mathrm{~cm}^{-1}$. This indicates adsorption of both the collectors on all the three copper mineral surfaces. However, the spectrum of chalcopyrite shows two strong peaks at 883 and $985 \mathrm{~cm}^{-1}$, characterising $\mathrm{P}-\mathrm{O}-\mathrm{C}$ symmetric and asymmetric stretching vibration respectively. Additionally, it also indicates peaks at 1065 and $1273 \mathrm{~cm}^{-1}$, corresponding to $\mathrm{C}=\mathrm{S}$ and $\mathrm{C}-\mathrm{N}$ stretching respectively. Similarly, the chalcocite spectrum depicts peaks at $895 \mathrm{~cm}^{-1}$ and $764 \mathrm{~cm}^{-1}$, implying P-O-C symmetric stretching vibrations. A semi-broad peak is also observed at 
$1192 \mathrm{~cm}^{-1}$, indicating C-O-C asymmetric stretching. However, bornite indicates two strong peaks at 1208 and $1351 \mathrm{~cm}^{-1}$ : C-N stretching and C-O-C asymmetric stretching respectively. The characteristic peaks related to DBD were also observed at 633 and $745 \mathrm{~cm}^{-1}$. These spectra reveal that DBD is more strongly adsorbed than the SIBX collector on chalcopyrite and chalcocite. Similarly, the adsorption of the SIBX collector is stronger for bornite as compared to DBD. The infrared spectroscopy results are consistent with the zeta potential and Hallimond flotation results. All the information regarding the bands and peaks are summarized in Table 1.

Table 1. The FTIR bands of dithiophosphate, $\mathrm{Cu}$-dithiophosphate precipitate, xanthate and chalcopyrite, chalcocite and bornite (before and after adsorption of dithiophosphate/dithiophosphate-xanthate blend, 1:1).

\begin{tabular}{|c|c|c|c|}
\hline Spectrum Name & Bands $\left(\mathrm{cm}^{-1}\right)$ & Significance & References \\
\hline \multirow{9}{*}{ Dithiophosphate (DBD) } & 531 & $\mathrm{v}_{\mathrm{S}}(\mathrm{P}-\mathrm{S})$ & {$[32,33]$} \\
\hline & 614 & $\mathrm{v}_{\mathrm{S}}(\mathrm{P}=\mathrm{S})$ & {$[32,33]$} \\
\hline & 735 & $\mathrm{v}_{\mathrm{S}}(\mathrm{P}-\mathrm{O}-\mathrm{C})$ & {$[28,32]$} \\
\hline & 787 & $\mathrm{v}_{\mathrm{S}}(\mathrm{P}-\mathrm{O}-\mathrm{C})$ & {$[32,33]$} \\
\hline & 828 & $\mathrm{v}_{\mathrm{S}}(\mathrm{P}-\mathrm{O}-\mathrm{C})$ & {$[28,32]$} \\
\hline & 860 & $\mathrm{v}_{\mathrm{S}}(\mathrm{P}-\mathrm{O}-\mathrm{C})$ & [32] \\
\hline & 907 & $\mathrm{v}_{\text {as }}(\mathrm{P}-\mathrm{O}-\mathrm{C})$ & [32] \\
\hline & 984 & $\mathrm{v}_{\text {as }}(\mathrm{P}-\mathrm{O}-\mathrm{C})$ & [32] \\
\hline & 1036 & $\mathrm{v}_{\text {as }}(\mathrm{P}-\mathrm{O}-\mathrm{C})$ & [32] \\
\hline \multirow{6}{*}{ Cu-dithiophosphate } & 523 & $\mathrm{v}_{\mathrm{S}}(\mathrm{P}-\mathrm{S})$ & {$[32,33]$} \\
\hline & 642 & $\mathrm{v}_{\mathrm{S}}(\mathrm{P}=\mathrm{S})$ & [32] \\
\hline & 746 & $\mathrm{v}_{\mathrm{S}}(\mathrm{P}-\mathrm{O}-\mathrm{C})$ & [33] \\
\hline & 833 & $\mathrm{v}_{\mathrm{S}}(\mathrm{P}-\mathrm{O}-\mathrm{C})$ & {$[32,33]$} \\
\hline & 970 & $\mathrm{v}_{\text {as }}(\mathrm{P}-\mathrm{O}-\mathrm{C})$ & {$[32,33]$} \\
\hline & 1168,1255 & $\mathrm{v}_{\text {as }}(\mathrm{P}-\mathrm{O}-\mathrm{C})$ & {$[32]$} \\
\hline \multirow{6}{*}{ Xanthate (SIBX) } & 1047 & $\mathrm{v}_{\mathrm{S}}(\mathrm{C}=\mathrm{S})$ & [34] \\
\hline & 1065 & $\mathrm{v}_{\mathrm{S}}(\mathrm{C}=\mathrm{S})$ & {$[32,34]$} \\
\hline & 1086 & $\mathrm{v}_{\mathrm{S}}(\mathrm{C}=\mathrm{S})$ & {$[32,33]$} \\
\hline & 1169 & $\mathrm{v}_{\text {as }}(\mathrm{C}-\mathrm{O}-\mathrm{C})$ & {$[32,33]$} \\
\hline & 1254 & $\mathrm{v}(\mathrm{C}-\mathrm{N})$ & {$[32,34]$} \\
\hline & 1508 & $\mathrm{v}(\mathrm{C}-\mathrm{N})$ & {$[34]$} \\
\hline \multirow{5}{*}{ Chalcopyrite + DBD } & 530 & $\mathrm{v}_{\mathrm{S}}(\mathrm{P}-\mathrm{S})$ & {$[32,33]$} \\
\hline & 571 & $\mathrm{v}_{\mathrm{S}}(\mathrm{P}-\mathrm{S})$ & {$[32]$} \\
\hline & 692 & $\mathrm{v}_{\mathrm{S}}(\mathrm{P}-\mathrm{O}-\mathrm{C})$ & {$[32,34]$} \\
\hline & 777 & $\mathrm{v}_{\mathrm{S}}(\mathrm{P}-\mathrm{O}-\mathrm{C})$ & {$[32,33]$} \\
\hline & 964 & $\mathrm{v}_{\text {as }}(\mathrm{P}-\mathrm{O}-\mathrm{C})$ & {$[32,33]$} \\
\hline \multirow{5}{*}{ Bornite + DBD } & 486 & $\mathrm{v}_{\mathrm{S}}(\mathrm{P}-\mathrm{S})$ & {$[32,33]$} \\
\hline & 623 & $\mathrm{v}_{\mathrm{S}}(\mathrm{P}=\mathrm{S})$ & {$[32,34]$} \\
\hline & 635 & $\mathrm{v}_{\mathrm{S}}(\mathrm{P}=\mathrm{S})$ & [32-34] \\
\hline & 814 & $\mathrm{v}_{\mathrm{S}}(\mathrm{P}-\mathrm{O}-\mathrm{C})$ & {$[32,33]$} \\
\hline & 949 & $\mathrm{v}_{\text {as }}(\mathrm{P}-\mathrm{O}-\mathrm{C})$ & {$[32,33]$} \\
\hline \multirow{5}{*}{ Chalcocite + DBD } & 625 & $\mathrm{v}_{\mathrm{S}}(\mathrm{P}=\mathrm{S})$ & [32] \\
\hline & 683 & $\mathrm{v}_{\mathrm{S}}(\mathrm{P}-\mathrm{O}-\mathrm{C})$ & \\
\hline & 773 & $\mathrm{v}_{\mathrm{S}}(\mathrm{P}-\mathrm{O}-\mathrm{C})$ & {$[32,33]$} \\
\hline & 953 & $\mathrm{v}_{\text {as }}(\mathrm{P}-\mathrm{O}-\mathrm{C})$ & {$[32,33]$} \\
\hline & 1024 & $\mathrm{v}_{\text {as }}(\mathrm{P}-\mathrm{O}-\mathrm{C})$ & {$[32,33]$} \\
\hline \multirow{4}{*}{ Chalcopyrite + DBD + SIBX } & 584 & $\mathrm{v}_{\mathrm{S}}(\mathrm{P}-\mathrm{S})$ & [32] \\
\hline & 883 & $\mathrm{v}_{\mathrm{S}}(\mathrm{P}-\mathrm{O}-\mathrm{C})$ & [32-34] \\
\hline & 985 & $\mathrm{v}_{\text {as }}(\mathrm{P}-\mathrm{O}-\mathrm{C})$ & \\
\hline & 1065 & $\mathrm{v}_{\text {as }}(\mathrm{C}-\mathrm{O}-\mathrm{C})$ & \\
\hline \multirow{5}{*}{ Bornite + DBD + SIBX } & 589 & $\mathrm{v}_{\mathrm{S}}(\mathrm{P}-\mathrm{S})$ & [32-34] \\
\hline & 663 & $\mathrm{v}_{\mathrm{S}}(\mathrm{P}-\mathrm{O}-\mathrm{C})$ & [32] \\
\hline & 1208 & $\mathrm{v}(\mathrm{C}-\mathrm{N})$ & [33] \\
\hline & 1351 & $\mathrm{v}(\mathrm{C}-\mathrm{N})$ & [34] \\
\hline & 1428 & $\mathrm{v}(\mathrm{C}-\mathrm{N})$ & {$[32,33]$} \\
\hline \multirow{4}{*}{ Chalcocite + DBD + SIBX } & 717 & $\mathrm{v}_{\mathrm{S}}(\mathrm{P}-\mathrm{O}-\mathrm{C})$ & {$[32,33]$} \\
\hline & 848 & $\mathrm{v}_{\mathrm{S}}(\mathrm{P}-\mathrm{O}-\mathrm{C})$ & {$[32,33]$} \\
\hline & 935 & $\mathrm{v}_{\text {as }}(\mathrm{P}-\mathrm{O}-\mathrm{C})$ & {$[32,33]$} \\
\hline & 1186 & $\mathrm{v}_{\text {as }}(\mathrm{C}-\mathrm{O}-\mathrm{C})$ & [32-34] \\
\hline
\end{tabular}




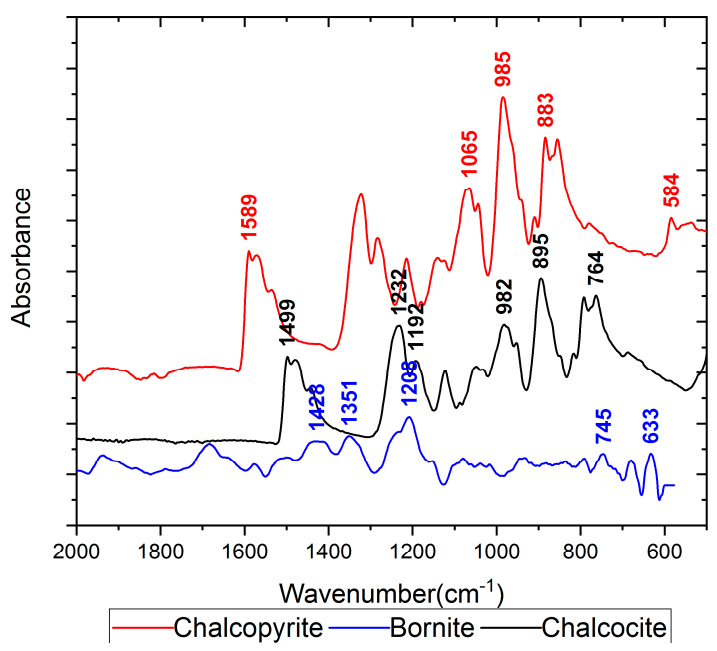

Figure 20. The DRIFT spectra of the dithiophosphate and xanthate collector blend (1:1) adsorption on copper sulphides at $\mathrm{pH} 8$ and a total concentration of collector $3 \times 10^{-5} \mathrm{M}$.

\subsection{Correlation among the Pure Mineral Studies with Respect to Collector Concentration}

Figure 21 shows the correlation between the Hallimond flotation recovery, Zeta Potential results and adsorption densities for the mixed collector system (SIBX:DBD $=1: 1)$ on the three copper minerals at collector concentration $3 \times 10^{-5} \mathrm{M}$ at $\mathrm{pH}$ 8. Figure 21a-c indicates a significant decrease in the zeta potential values at the total collector concentration $\left(3 \times 10^{-5} \mathrm{M}\right)$; at the same concentration, the floatability of the $\mathrm{Cu}$-minerals increased. The adsorption of DBD is approximately constant above collector concentration $3 \times 10^{-5} \mathrm{M}$. Xanthate adsorption is less pronounced at this concentration. Thus, a good correlation is observed among all the pure mineral results on all the three copper minerals.

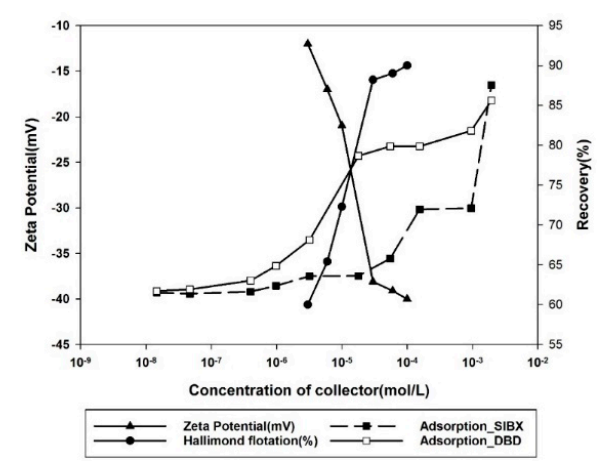

(a)
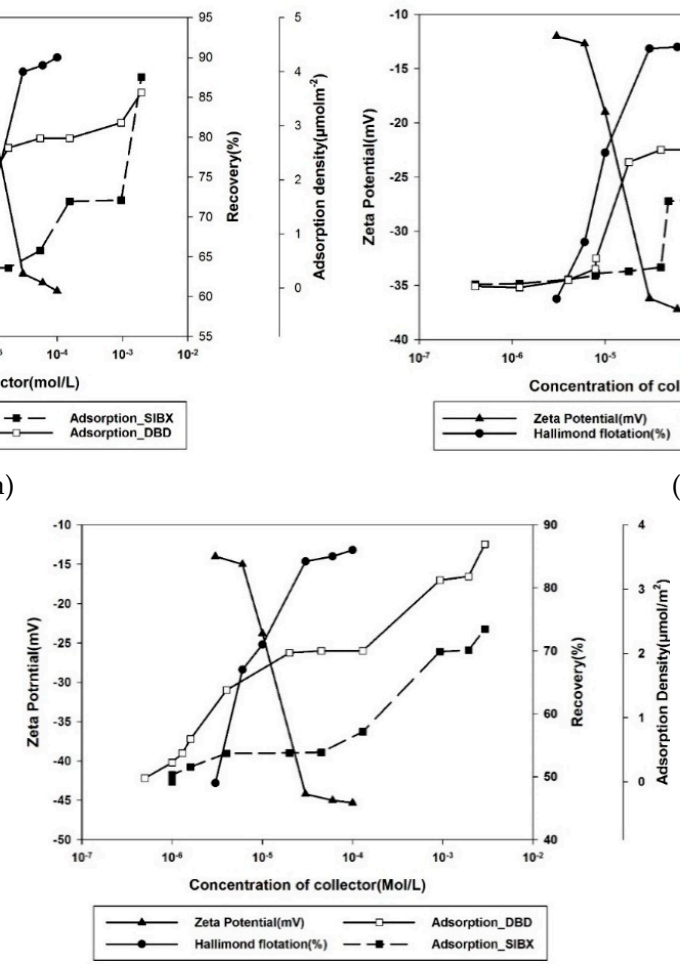

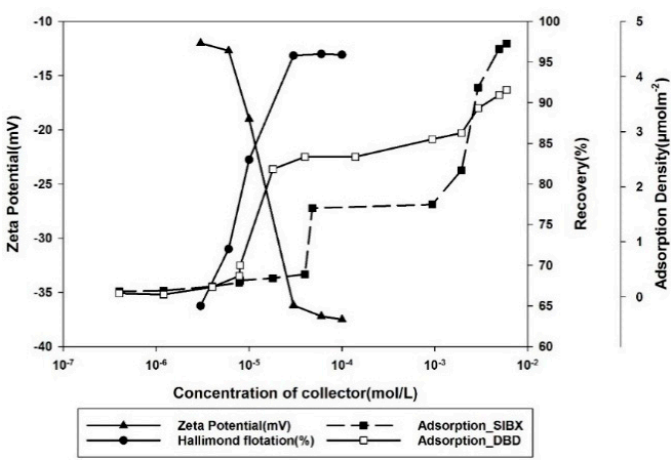

(b)

(c)

Figure 21. The correlation between the Hallimond flotation recovery, zeta potential results and adsorption densities for (a) chalcopyrite, (b) chalcocite, and (c) bornite at a total collector concentration $3 \times 10^{-5} \mathrm{M}$ (SIBX:DBD ratio 1:1) at natural $\mathrm{pH}$. 


\subsection{Bench Scale Flotation}

The natural ore flotation was carried out using DBD as the collector and MIBC as frother as a function of $\mathrm{pH}$. Lime or any other additive was not employed in the current study because the ore does not contain iron sulphide gangue minerals. The feasibility of copper sulphide flotation with the collector DBD and mixtures of DBD and SIBX for the coarse grind samples $(-105 \mu \mathrm{m})$ were tested and are reported in this study. As per the mineralogical studies, the copper sulphides are liberated (>80\%) in this size range; the major middlings' percentage are copper sulphide-copper sulphide associations.

The results are presented in Table 2 . At $\mathrm{pH} 4$, recovery is considerable and close to $90 \%$ with a total concentrate grade of $17 \%$. In the alkaline region, at $\mathrm{pH} 12$, the grade is low, approximately $10.7 \%$, but the recovery is above $90 \%$. At natural $\mathrm{pH}(\mathrm{pH} 8)$, the recovery is maximum, approximately $95 \%$ with a concentrate grade of $19.4 \%$. The flotation response of Nussir ore with SIBX as a reagent produced a highest concentration grade of $14 \%$ [19], Thus, the copper concentrate grade is significantly improved by using DBD as a collector due to the high selectivity of the collector towards copper minerals. The results are consistent with the pure mineral studies. Table 3 represents the recovery and grade results for the mixed collector systems at natural $\mathrm{pH}$. The table indicates that all results of the collector combinations are better as compared to a single collector system. Thus, the results are in agreement with the previous findings in the literature [35], understandably due to the synergistic action of reagents which leads to higher flotation of copper sulphides. Overall, the best results were obtained for SIBX:DBD = 1:3 at natural $\mathrm{pH}$, which showed a recovery of $96.3 \%$ with a concentrate grade of $24.7 \%$. The results can be correlated with the pure mineral studies. It was observed in the microscopic analysis that the ore has bornite in major quantity. Therefore, the mixture with DBD at a higher proportion in the reagent mixture is the best suited reagent scheme proposed for this ore.

The reagent mixture, with total concentration $3 \times 10^{-5} \mathrm{M}$, produced the best grades and recoveries. Thus, the reagent concentration can be reduced by using the mixed collector system with improved metallurgical results.

Table 2. The grade and Recovery results with respect to varying $\mathrm{pH}$ at collector concentration $5 \times 10^{-5} \mathrm{M}$. Feed grades $2.2 \%-2.5 \%$.

\begin{tabular}{cccc}
\hline Samples Conc/Tail & $\mathbf{p H}$ & Copper Grade (\%) & Copper Recovery \\
\hline Conc_1 & & 34 & 86.7 \\
Conc_2 & 4 & 1.3 & 3.3 \\
Tail & & 0.2 & 9.4 \\
Head Bal. & & 17.4 & 90.0 \\
Total Mass Bal. & & & 99.4 \\
\hline Conc_1 & \multirow{2}{*}{} & 42.6 & 93.3 \\
Conc_2 & & 1.1 & 2.0 \\
Tail & & 0.1 & 4.5 \\
Head Bal. & 19.4 & 95.3 \\
Total Mass Bal. & & 99.8 \\
\hline Conc_1 & & 92.2 \\
Conc_2 & 8 & 0.9 & 1.8 \\
Tail & & 0.1 & 4.72 \\
Head Bal. & 19.4 & 94.6 \\
Total Mass Bal. & & 99.3 \\
\hline Conc_1 & & 46 & 83.1 \\
Conc_2 & 12 & 1.1 & 7.3 \\
Tail & & 10.1 & 8.6 \\
Head Bal. & & & 90.4 \\
Total Mass Bal. & & & 99.0 \\
\hline
\end{tabular}


Table 3. The grade and Recovery results with respect to varying collector concentration. Feed grades $2.2 \%-2.5 \%$.

\begin{tabular}{cccc}
\hline Samples Conc/Tail & Collector Conc. & Copper Grade (\%) & Copper Recovery \\
\hline Conc_1 & & 42.8 & 93.4 \\
Conc_2 & $2 \times 10^{-5} \mathrm{M}(\mathrm{D})$ & 1.05 & 2.41 \\
Tail & $1 \times 10^{-5} \mathrm{M}(\mathrm{S})$ & 0.1 & 3.3 \\
Head Bal. & & 21.4 & 95.8 \\
Total Mass Bal. & & 30.1 & 99.2 \\
\hline Conc_1 & $1 \times 10^{-5} \mathrm{M}(\mathrm{D})$ & 2.21 & 90.4 \\
Conc_2 & $2 \times 10^{-5} \mathrm{M}(\mathrm{S})$ & 0.1 & 3.95 \\
Tail & & 19.6 & 4.7 \\
Head Bal. & & 94.4 \\
Total Mass Bal. & & 47.3 & 99.1 \\
\hline Conc_1 & & 1.5 & 93.5 \\
Conc_2 & 0.07 & 3.01 \\
Tail & & 24.7 & 3.01 \\
Head Bal. & $0.75 \times 10^{-5} \mathrm{M}(\mathrm{S})$ & & 96.3 \\
Total Mass Bal. & & 27.9 & 99.4 \\
\hline Conc_1 & & 2.1 & 94.8 \\
Conc_2 & & 0.1 & 1.91 \\
Tail & & 22.3 & 4.42 \\
Head Bal. & $2.25 \times 10^{-5} \mathrm{M}(\mathrm{S})$ & & 96.6 \\
Total Mass Bal. & & 99.3
\end{tabular}

D, DBD; S, SIBX; Bal., Balance.

\section{Conclusions}

The copper mineralogy of Nussir copper ore primarily comprises chalcopyrite, chalcocite and bornite. Microscopic analyses showed the copper sulphides are more than $80 \%$ liberated in the $-105 \mu \mathrm{m}$ size fraction samples. It was also revealed that approximately $10 \%-17 \%$ of copper sulphides are associated with each other or other gangue minerals and that these mineral mixtures were difficult to float with xanthate collectors. Therefore, an attempt was made to employ a dithiophosphate collector (DBD) and a mixture of DBD-SIBX collectors to float these copper minerals from the ore.

The zeta potential studies of copper minerals after interaction with DBD showed that the mineral surfaces acquired a comparatively more negative charge due to the chemical adsorption of the collector on the surface, chiefly on the Cu-sites. In the case of chalcopyrite, chalcocite and bornite, the zeta potential values significantly decrease with a higher proportion of DBD in the reagent mixture. Another important observation was that at alkaline $\mathrm{pH}$ values, the zeta potential values of copper minerals were less influenced by increases in the collector concentration; this is due to the prevalence of metal hydroxide, which diminishes the adsorption of collector on the copper minerals.

Single mineral flotation results indicate a low recovery of all the three copper minerals at $\mathrm{pH} 4$ while the best recovery was found in the $\mathrm{pH}$ range 6 to 10 and the recovery decreases marginally at very alkaline $\mathrm{pH}(>10)$. The recovery of chalcopyrite was consistently higher until $\mathrm{pH} 10$, which decreases insignificantly beyond this $\mathrm{pH}$ value. However, the flotation response of gangue minerals (calcite and quartz) are negligible at natural $\mathrm{pH}$. Based on data from the pure mineral studies, it can be stated that the copper sulphides can be floated in the natural $\mathrm{pH}$ region at a DBD concentration of $5 \times 10^{-5} \mathrm{M}$. When xanthate and dithiophosphate mixtures were employed as collectors, the recovery was always higher than a single collector system. The highest recoveries of all the three copper minerals were observed for SIBX:DBD at 1:2, when the proportion of DBD was greater in the mixture.

The FTIR spectral studies indicated that the interaction of dithiophosphate on copper sulphides was due to chemical reactions. The adsorption results obtained with chalcopyrite, chalcocite and bornite indicate the surface species formed to be $\mathrm{Cu}$-(DBD). The spectra of copper sulphides 
conditioned with a mixed collector (1:1) show both the xanthate and dithiophosphate characteristic bands on the three copper minerals. However, strong peaks of the more selective collector DBD are observed on the chalcopyrite and chalcocite spectra, while strong peaks of SIBX are observed on the bornite spectrum. The quantitative adsorption results showed that DBD was adsorbed on the chalcopyrite and bornite surface at far lower concentrations $\left(1 \times 10^{-6} \mathrm{M}\right)$, whereas the onset of adsorption on chalcocite was at a relatively higher concentration $\left(1 \times 10^{-5} \mathrm{M}\right)$. All the three isotherms depict less than monolayer coverage; however, a higher concentration of collector was required for bornite to achieve saturation. The adsorption of the mixture of dithiophosphate and xanthate in the ratio 1:1 on the three copper sulphides indicated that DBD adsorbs preferentially on chalcopyrite and chalcocite surfaces, whereas SIBX adsorbs preferentially on the bornite. The results were substantiated by the area under the alkyl chain region and the intensity of characteristic peaks of DBD and SIBX in the FTIR spectra. Thus, it is clear from these results that the more selective collector adsorbs first on the copper mineral surface followed by the less selective collector.

The bench scale flotation results of a Nussir ore sample with a DBD collector indicated that at natural $\mathrm{pH}$ and collector concentration $5 \times 10^{-5} \mathrm{M}$, the optimum cumulative concentrate grade obtained was $19.6 \%$ copper with a recovery of $94.9 \%$. The bench scale flotation with a mixed collector scheme showed the synergistic action of the collectors and the grade is improved for the various proportions of collector mixture at lower total collector concentration. A higher proportion of DBD in the collector blend resulted in a higher cumulative recovery (96\%) and grade (24.7\%) of copper. The pure mineral studies are consistent with the bench scale flotation results. In summary, the copper minerals in the Nussir deposit could be exploited with better metallurgical results using dithiophosphates and xanthate collector mixtures.

Author Contributions: P.D. carried out the experimental part, interpreted the data and wrote the manuscript. M.T. edited the manuscript, made the necessary English corrections and contributed in the final formatting. H.R.K. also contributed in the interpretation of data and reviewed the manuscript. H.R.K. also provided the resources and project administration and reviewed and edited the manuscript.

Funding: This research received no external funding.

Acknowledgments: The authors would like to acknowledge financial support from Norwegian University of Science and Technology (NTNU). Laurentius Tijhuis and Torill Sørløkk at the Department of Geoscience and Petroleum, NTNU, Norway must be thanked for characterising the samples by XRD and XRF. We would also acknowledge the Department of Matériaux et Environement, Université de Liège, Belgium for their guidance when using the Zeiss Mineralogic mining equipment. One of the authors, Priyanka Dhar, wishes to express her gratitude to Nussir ASA for providing the ore samples for this work.

Conflicts of Interest: The authors declare no conflict of interest.

\section{References}

1. Moen, K. Geological and Mineralogical Investigation of The Western Part of The Nussir Copper Deposit-With Focus on the Geological Relationship between the Upper- and the Lower Mineralized Horizons. Master's Thesis, Norwegian University of Science and Technology, Trondheim, Norway, 2014.

2. Dhar, P.; Hassan, B.; Aasly, K.; Thornhill, M.; Kota, H.R. Flotation flowsheet development for the new Nussir ASA copper ore deposit in northern Norway. In Proceedings of the XXIX International Mineral Processing Congress, Moscow, Russia, 15-21 September 2018.

3. Buckley, A.N.; Woods, R. Underpotential deposition of dithiophosphate on chalcocite. J. Electroanal. Chem. 1993, 357, 387-405. [CrossRef]

4. Chander, S.; Fuerstenau, D.W. The effect of potassium diethyl dithiophosphate on the electrochemical properties of platinum, copper and copper sulphide in aqueous solution. J. Electroanal. Chem. Interfac. Chem. 1974, 56, 217-247. [CrossRef]

5. Güler, T.; Hicyilmaz, C.; Gokagac, G.; Emekci, Z. Adsorption of dithiophosphate and dithiophosphinate on chalcopyrite. Miner. Eng. 2006, 19, 62-71. [CrossRef]

6. Leja, J. Surface Chemistry of Froth Flotation; Plenum: New York, NY, USA, 1982; ISBN 0306405881. 
7. Woods, R. Electrochemistry of sulphide flotation. In Flotation: A.M. Gaudin Memorial Volume; Fuerstenau, M.C., Ed.; American Institute of Mining, Metallurgical and Petroleum Engineers: New York, NY, USA, 1976; pp. 298-333.

8. Zhong, H.; Huang, Z.; Zhao, G.; Wang, S.; Liu, G.; Cao, Z. The collecting performance and interaction mechanism of sodium diisobutyl dithiophosphinate in sulfide minerals flotation. J. Mater. Res. Technol. 2015, 4, 151-161. [CrossRef]

9. Glembotskii, A.A. The combined action of collectors during flotation. Tsvetnye Met. 1958, 4, 6-14. (In Russian)

10. Bradshaw, D.J.; O' Connor, C.T. The flotation of pyrite using mixtures of dithiocarbamates and other thiol collectors. Miner. Eng. 1994, 7, 681-690. [CrossRef]

11. Bradshaw, D.J.; Harris, P.J.; O'Connor, C.T. Synergistic interactions between reagents in sulphide flotation. J. S. Afr. Inst. Min. Metall. 1998, 98, 189-194.

12. Lotter, N.O.; Bradshaw, D.J. The formulation and use of mixed collectors in sulphide flotation. Miner. Eng. 2010, 23, 945-951. [CrossRef]

13. Wakamatsu, T.; Numata, Y.; Park, C.H. Fundamental study of the flotation of minerals using two kinds of collectors. In Fine Particles Processing, Proceedings of the International Symposium on Fine Particles Processing, Las Vegas, NV, USA, 24-28 February; Somasundaran, P., Ed.; AIME: New York, NY, USA, 1980; Volume 1, pp. 787-801.

14. Corin, K.C.; Bezuidenhout, J.C.; O'Connor, C.T. The role of dithiophosphate as a co-collector in the flotation of a platinum group mineral ore. Miner. Eng. 2012, 36-38, 100-104. [CrossRef]

15. McFadzean, B.; Castelyn, D.G.; O'Connor, C.T. The effect of mixed thiol collectors on the flotation of galena. Miner. Eng. 2012, 36-38, 211-218. [CrossRef]

16. McFadzean, B.; Mhlanga, S.S.; O'Connor, C.T. The effect of thiol collector mixtures on the flotation of pyrite and galena. Miner. Eng. 2013, 50-51, 121-129. [CrossRef]

17. Bagci, E.; Ekmekci, Z.; Bradshaw, D.J. Adsorption behaviour of xanthate and dithiophosphinate from their mixtures on chalcopyrite. Miner. Eng. 2007, 20, 1047-1053. [CrossRef]

18. Critchley, J.K.; Riaz, M. Study of synergism between xanthate and dithiocarbamate collectors in flotation of heazlewoodite. Trans. Inst. Min. Metall. 1991, 100, C55-C57.

19. Bouzahzah, H.; Benzaazoua, M.; Mermillod-Blondin, R.; Pirard, E. A novel procedure for polished section preparation for automated mineralogy avoiding internal particle settlement. In Proceedings of the 12th International Congress for Applied Mineralogy (ICAM), Istanbul, Turkey, 10-12 August 2015.

20. Dhar, P.; Thornhill, M.; Rao, K.H. Investigation of copper recovery from a new copper deposit (Nussir) in northern-Norway: Xanthates as collectors. Miner. Process. Metall. Rev. 2018, submitted.

21. Zhao, K.L.; Gu, G.H.; Wang, X.; Wang, C.L.; Wang, X.H.; Luo, G.H. Influence of depressant foenum-graecum on the flotation of a sulphide ore which contains hydrophobic gangue. Int. J. Miner. Process. 2015, 141, 68-76. [CrossRef]

22. Kelebek, S.; Smith, G.W. Electro-kinetic properties of a galena and chalcopyrite with a collectorless flotation behaviour. Colloids Surf. 1989, 40, 137. [CrossRef]

23. Fullston, D.; Fornasiero, D.; Ralston, J. Zeta potential study of the oxidation of copper sulphide minerals. Colloids Surf. A Physicochem. Eng. Asp. 1999, 146, 113-121. [CrossRef]

24. Somasundaran, P. (Ed.) Advances in Mineral Processing; SME: Littleton, CO, USA, 1986; pp. 154-170.

25. Grano, S.R.; Cnossen, H.; Skinner, W.; Prestidge, C.A.; Ralston, J. Surface modifications in the chalcopyrite-sulphite ion system, II. Dithiophosphate collector adsorption study. Int. J. Miner. Process. 1997, 50, 27-45. [CrossRef]

26. Raju, G.B.; Forsling, W. Adsorption of Thiol Collectors on Chalcopyrite. J. Surf. Sci. Technol. 1997, 13, 25-37.

27. Matsuoka, I.; Ichikoku, T. Study on collection of galena by dithiophosphates. J. Min. Metall. Inst. Jpn. 1982, 98, 423-428.

28. Petrus, H.T.B.M.; Hirajima, T.; Sasaki, K.; Okamoto, H. Study of diethyl dithiophosphate adsorption on chalcopyrite and tennantite at varied pHs. J. Min. Sci. 2011, 47, 695. [CrossRef]

29. Ackerman, P.K.; Harris, G.H.; Klimpel, R.R.; Aplan, F.F. Evaluation of flotation collectors for copper sulphides and pyrite, I. Common sulfhydryl collectors. Int. J. Miner. Proc. 1987, 21, 105-140. [CrossRef]

30. Nagaraj, M.E.; Lewellyn, S.S.; Wang, P.A.; Scanlon, M.J. New sulfide and precious metals collector: for acid, neutral and mildly alkaline circuits. In Proceedings of the International Mineral Processing Congress, Stockholm, Sweden, 5-10 June 1988. 
31. Leppinen, J. FTIR and Flotation Investigations of Adsorption of Diethyldithiophosphate on Sulphide Minerals; Report No. 726; Technical Research Centre of Finland: Espoo, Finland, 1991.

32. Colthup, N.B.; Daly, L.H.; Wiberley, S.E. Introduction to Infrared and Raman Spectroscopy, 3rd ed.; Academic Press: San Diego, CA, USA, 1990.

33. Güler, T.; Hiçyılmaz, C.; Gökağaç, G.; Ekmekçi, Z. Electrochemical behaviour of chalcopyrite in the absence and presence of dithiophosphate. Int. J. Miner. Process. 2005, 75, 217-228. [CrossRef]

34. Bellamy, L. The Infra-Red Spectra of Complex Molecules; John Wiley \& Sons: London, UK, 1975; ISBN 94-011-6520-3.

35. Buckley, A.N.; Hope, G.A.; Parker, G.K.; Steyn, J.; Woods, R. Mechanism of mixed dithiophosphate and mercaptobenzothiazole collectors for Cu sulfide ore minerals. Miner. Eng. 2017, 109, 80-97. [CrossRef]

(C) 2019 by the authors. Licensee MDPI, Basel, Switzerland. This article is an open access article distributed under the terms and conditions of the Creative Commons Attribution (CC BY) license (http:// creativecommons.org/licenses/by/4.0/). 